\title{
Grass Carp Follisatin: Molecular Cloning, Functional Characterization, Dopamine D1 Regulation at Pituitary Level, and Implication in Growth Hormone Regulation
}

\author{
Roger S. K. Fung, Bai Jin, Mulan He, Karen W. Y. Yuen and Anderson O. L. Wong*
}

School of Biological Sciences, University of Hong Kong, Hong Kong, Hong Kong

Activin is involved in pituitary hormone regulation and its pituitary actions can be nullified by local production of its binding protein follistatin. In our recent study with grass carp, local release of growth hormone (GH) was shown to induce activin expression at pituitary level,

OPEN ACCESS

Edited by: Ishwar Parhar,

Monash University, Australia

Reviewed by:

Takashi Yada,

Japan Fisheries Research and Education Agency (FRA), Japan

Gustavo M. Somoza,

Instituto de Investigaciones Biotecnologicas-Instituto Tecnologico de Chascomus (IIB-INTECH),

Argentina

Wei Ge,

University of Macau, China

*Correspondence:

Anderson O. L. Wong olwong@hku.hk

Specialty section:

This article was submitted to Experimental Endocrinology,

a section of the journal

Frontiers in Endocrinology

Received: 11 July 2017 Accepted: 09 August 2017 Published: 24 August 2017

Citation:

Fung RSK, Jin B, He M, Yuen KWY and Wong AOL (2017) Grass Carp Follisatin: Molecular Cloning, Functional Characterization, Dopamine D1 Regulation at Pituitary Level, and Implication in Growth Hormone Regulation.

Front. Endocrinol. 8:211. doi: 10.3389/fendo.2017.00211 which in turn could exert an intrapituitary feedback to inhibit GH synthesis and secretion. To further examine the activin/follistatin system in the carp pituitary, grass carp follistatin was cloned and confirmed to be single-copy gene widely expressed at tissue level. At the pituitary level, follistatin signals could be located in carp somatotrophs, gonadotrophs, and lactotrophs. Functional expression also revealed that carp follistatin was effective in neutralizing activin's action in stimulating target promoter with activin-responsive elements. In grass carp pituitary cells, follistatin co-treatment was found to revert activin inhibition on GH mRNA expression. Meanwhile, follistatin mRNA levels could be up-regulated by local production of activin but the opposite was true for dopaminergic activation with dopamine (DA) or its agonist apomorphine. Since GH stimulation by DA via pituitary D1 receptor is well-documented in fish models, the receptor specificity for follistatin regulation by DA was also investigated. Using a pharmacological approach, the inhibitory effect of DA on follistatin gene expression was confirmed to be mediated by pituitary D1 but not D2 receptor. Furthermore, activation of D1 receptor by the D1-specific agonist SKF77434 was also effective in blocking follistatin mRNA expression induced by activin and GH treatment both in carp pituitary cells as well as in carp somatotrophs enriched by density gradient centrifugation. These results, as a whole, suggest that activin can interact with dopaminergic input from the hypothalamus to regulate follistatin expression in carp pituitary, which may contribute to $\mathrm{GH}$ regulation by activin/follistatin system via autocrine/paracrine mechanisms.

Keywords: follistatin, activin, dopamine, growth hormone, pituitary, grass carp

\section{INTRODUCTION}

Follistatin, a glycoprotein first isolated in porcine follicular fluid by its activity to inhibit folliclestimulating hormone (FSH) secretion (1), can bind activin with high affinity and nullify its biological actions by preventing its binding and subsequent activation of type I and II activin receptors expressed at tissue level (2). The molecular structure of follistatin is highly conserved from fish to

Abbreviations: GH, growth hormone; LH, luteinizing hormone; FSH, follicle-stimulating hormone; PRL, prolactin; hCG, human chorionic gonadotropin; DA, dopamine; APO, apomorphine; LCM, laser capture microdissection. 
mammals (3). At tissue level, e.g., in the pituitary (4) and ovarian follicle (5), co-expression of follistatin and activin is frequently observed and follistatin expression is highly inducible by activin, which constitutes a local feedback for signal termination of activin actions (6). At cellular level, follistatin expression (e.g., in skeletal myoblast) is mediated via RSPO-LGR4 signaling (7) and Wnt/ $\beta$ catenin pathway (8). In general, activin and its binding protein follistatin are widely expressed in various tissues and play a role in diverse functions including folliculogenesis (9), spermatogenesis (10), implantation and pregnancy $(11,12)$, regulation of pituitary hormones (13), energy metabolism (14), adipocyte differentiation (15), inflammation and immune responses (16), wound healing/ tissue repair $(17,18)$, and stem cell survival during embryonic development (19). Aberrant expression/dysregulation of activin/ follistatin system is also associated with carcinogenesis and tumorigenesis, e.g., in prostate cancer (20). Given that follistatin can also induce muscle growth and development via its binding with myostatin expressed in skeletal myoblasts (21), its potential application in "muscling"/growth promotion of farm animals has been a focus for recent development of agricultural biotechnology.

In mammals (e.g., rodents), the activin/follistatin system is a key component for reproductive function both in the pituitary (for gonadotropin regulation) and at the gonadal level (for oocyte/sperm maturation and steroid production) (5). In the rat pituitary, activin is expressed mainly in gonadotrophs (22) and stimulates FSH secretion and gene expression with parallel rise in $\mathrm{GnRH}$ receptor expression (23). The stimulatory effects of activin, however, could be inhibited by local production of follistatin (13), which is known to be originated mainly from folliculo-stellate cells (24), probably under the stimulatory influence of activin (25). In the same model, follistatin can also be located in gonadotrophs (26) and its expression could be up-regulated by $\mathrm{GnRH}$ and PACAP (4), implying that, besides the local action of activin, pituitary expression of follistatin is also under the influence of hypothalamic signals. Although activin in general is considered to have little/no effect on luteinizing hormone ( $\mathrm{LH})$, it is capable of inducing LH $\beta$ gene expression in pituitary cell lines (e.g., in L $\beta$ T2 cells) (27) and parallel regulation of growth hormone $(\mathrm{GH})$ and prolactin (PRL) release/gene expression has also been reported (e.g., in GH3 cells) $(28,29)$. At present, the functional role of follistatin in these "pituitary responses" is still unclear. In lower vertebrates, e.g., in fish models, the activin/follistatin system in the pituitary and its involvement in gonadotropin regulation appear to be well-conserved (30) and have been documented in the goldfish (31), zebrafish (32), and more recently in European eel (33). In fish species, interestingly, activin was found to have opposite effects on the two gonadotropins, with stimulation on FSH but inhibition on LH expression (31-33), and these differential effects could be blocked by follistatin at pituitary level, e.g., in zebrafish (32) and goldfish $(34,35)$. Of note, unlike the studies in mammals, cell-type-specific expression of follistatin has not been characterized in fish pituitary. Besides, hypothalamic regulation of pituitary follistatin as a means to modulate the functionality of activin/follistatin system has not been examined in fish models.

In grass carp, a representative member of carp family with high commercial value in Asian countries, our previous studies have shown that GH and LH released locally at pituitary level can play a role in autocrine/paracrine regulation of GH (36) and PRL synthesis and secretion (37). In grass carp pituitary, gonadotrophs exist in the form of cell clusters within the matrix of somatotrophs located in the proximal pars distalis (38) and local interactions between the two cell types are known to constitute an intrapituitary feedback for GH regulation (39). In this feedback loop, LH secretion from gonadotrophs can induce $\mathrm{GH}$ release and gene expression in neighboring somatotrophs via paracrine actions mediated by cAMP/PKA and JAK 2 /MAPK pathways (40). At somatotroph level, the stimulatory effects on $\mathrm{GH}$ expression can be further amplified by $\mathrm{GH}$ autoregulation via $\mathrm{GH}$-induced $\mathrm{GH}$ release and $\mathrm{GH}$ gene expression mediated by $\mathrm{JAK}_{2} / \mathrm{MAPK}$ and $\mathrm{JAK}_{2} / \mathrm{PI} 3 \mathrm{~K}$ cascades (41) and GH released locally in turn can trigger signal termination via paracrine inhibition of LH secretion from nearby goanadotrophs (39). In our recent study, activin was also found to interact with $\mathrm{GH}$ and $\mathrm{LH}$ released locally at pituitary level to modulate $\mathrm{GH}$ secretion and gene expression in grass carp (42). In this case, the two forms of activin $\beta$ subunits, activin $\beta \mathrm{A}$ and $\beta \mathrm{B}$, were shown to be up-regulated by $\mathrm{GH}$ treatment in carp pituitary cells via $\mathrm{JAK}_{2} / \mathrm{STAT}_{5}, \mathrm{MAPK}$, and PI3K/ Akt pathways and local production of activin $\mathrm{A}$ and $\mathrm{B}$ in turn could suppress $\mathrm{GH}$ release, $\mathrm{GH}$ production, and $\mathrm{GH}$ gene expression with concurrent drop in GH gene transcription via $\mathrm{SMAD}_{2} /$ $\mathrm{SMAD}_{3}$-dependent mechanisms (42). In the same study, both basal as well as $\mathrm{GH}$-induced activin $\beta \mathrm{A}$ and $\beta \mathrm{B}$ gene expression were also suppressed by $\mathrm{LH}$ released locally in carp pituitary cells, suggesting that activin may constitute as a new facet of the intrapituitary feedback loop for GH regulation.

In fish pituitary, direct innervation by dopaminergic fibers originated from the hypothalamus is well-documented (43, 44) and dopaminergic regulation of $\mathrm{GH}$ and $\mathrm{LH}$ release at the pituitary level has been reported in goldfish (45), tilapia (46), and rainbow trout (43). In fish models, interestingly, dopamine (DA) is known to induce GH release via activation of DA D1 receptor but inhibit $\mathrm{LH}$ secretion via DA D2 receptor expressed at pituitary level, e.g., in goldfish (47). In our previous study with grass carp pituitary cells, GH secretion induced by DA D1 induction has also been demonstrated (38) but the role of DA in pituitary regulation of activin/follistatin system is still unclear. In this study, as a follow-up of our investigation on GH regulation by activin/follistatin system in carp model, grass carp follistatin was cloned and its expression at tissue level, especially in the pituitary, was characterized by RT-PCR, Northern blot, and LC/ MS/MS. The functionality of carp follistatin in neutralizing the biological actions of activin was validated by protein expression followed by functional studies in mammalian cell lines. Using primary culture of grass carp pituitary cells, follistatin induction by activin, dopaminergic regulation of follistatin and activin, and follistatin modulation of $\mathrm{GH}$ expression under activin inhibition were examined at the pituitary level. Using a pharmacological approach, the receptor specificity for DA regulation of follisatin was elucidated and confirmed to be mediated through pituitary D1 receptor. To establish the link between follistatin and somatotroph function, the effects of DA D1 activation on follistatin expression induced by activin and GH treatment were also tested in carp somatotrophs enriched by density gradient centrifugation. Our studies for the first time provide evidence that the activin/ 
follistatin system within the carp pituitary can be regulated by dopaminergic input via pituitary D1 receptor and contribute to GH regulation via autocrine/paracrine mechanisms.

\section{MATERIALS AND METHODS}

\section{Animals and Test Substances}

Mixed sexes of grass carp (Ctenopharyngodon idellus) with body weight of $2.0-2.4 \mathrm{~kg}$ were obtained from local wholesale market and maintained in well-aerated aquaria at $20^{\circ} \mathrm{C}$ under 12 -h light:12-h dark photoperiod for 10-14 days prior to experimentation. For tissue sampling and pituitary cell preparation, the fish were sacrificed by anesthesia in 0.05\% MS222 (Sigma-Aldrich, St. Louis, MO, USA) followed by spinosectomy according to the protocol approved by the Committee for Animal Use in Teaching and Research at the University of Hong Kong (Hong Kong). For drug treatment, porcine $\mathrm{GH}$, human chorionic gonadotropin (hCG), and recombinant proteins for human activin A, activin B, and follistatin were obtained from Sigma-Aldrich while DA, its non-selective agonist apomorphine (APO), and agonists/antagonists for DA D1/D2 receptor, including SKF77434, SKF83566, Ly171555, and sulpiride were acquired from Calbiochem (San Diego, CA, USA). The protein hormones, activin, and follistatin used in our studies were dissolved in double-distilled water as $1 \mathrm{mM}$ stock solutions and stored frozen at $-80^{\circ} \mathrm{C}$ in small aliquots. APO and D1/D2 drugs were prepared in a similar manner except that they were dissolved in DMSO as $10 \mathrm{mM}$ stock solutions. During our experiments, except for DA which was freshly prepared right before drug treatment, frozen stocks of test substances were routinely diluted with prewarmed $\left(28^{\circ} \mathrm{C}\right)$ culture medium to appropriate concentrations $10 \mathrm{~min}$ prior to drug administration. The final dilutions of DMSO were always maintained at levels $\leq 0.1 \%$ and did not affect target gene expression in our cell culture system.

\section{Molecular Cloning, Gene Copy Number, and Tissue Expression of Carp Follistatin}

To establish the structural identity of grass carp follistatin, total RNA was isolated from the carp pituitary, reversely transcribed with SuperScript II (Invitrogen, Carlsbad, CA, USA) and used in $3^{\prime} / 5^{\prime}$ RACE with primers designed based on the conserved regions of follistatin in goldfish and zebrafish. Full-length cDNA for carp follistatin was compiled using MacVector 9.5 (Oxford Molecular, Madison, WI, USA). Sequence alignment, protein modeling, and phylogenetic analysis of follistatin sequence obtained were conducted using CLUSTAL-W (http://www.ebi.ac.uk/Tools/msa/ clustalw2), SWISS-MODEL (http://swissmodel.expasy.org/), and MEGA 6.0 (http://www.megasoftware.net), respectively. To study the gene copy number of follistatin in the carp genome, Southern blot was performed in genomic DNA isolated from the whole blood of grass carp (48) after digestion with restriction enzymes including Pvu II, Sty I, Bgl II, EcoR V, Xba I, BamH I, and Bgl I followed by hybridization with a DIG-labeled cDNA probe for follistatin.

For tissue expression profiling of follistatin, RT-PCR was carried out in total RNA prepared from selected tissues and brain areas with parallel PCR for $\beta$ actin expression as the internal control. In this case, the RT samples prepared after DNAse I digestion and reverse transcription (RT) of total RNA obtained from target tissues/brain areas were subjected to PCR using primers for carp follistatin (5'TAAATGCTTAACCTCCAGGAGAA3' and 5'ATCGCATGACTTGGCC TTGATG3'). PCR reactions were conducted for 35 cycles with denaturation at $94^{\circ} \mathrm{C}$ for $30 \mathrm{~s}$, annealing at $58^{\circ} \mathrm{C}$ for $30 \mathrm{~s}$, and extension at $72^{\circ} \mathrm{C}$ for $90 \mathrm{~s}$, and the authenticity of PCR product (292 bp) was confirmed by PCR Southern using the DIG-labeled probe for follistatin used in the preceding section. To shed light on the size and form(s) of follistatin transcript(s) expressed at the pituitary level, total RNA prepared from the carp pituitary was size-fractionated in $1 \%$ agarose gel and used in Northern blot (37) with a DIGlabeled riboprobe for follistatin. To confirm the presence of an activin/follistatin system in the carp pituitary, protein expression of follistatin and activin was also examined using LC/ MS/MS with pituitary lysate after trypsin digestion in a Sciex TripleTOF-5600 system (AB Sciex, Concord, ON, Canada) as described previously (49).

To test if follistatin also exhibits a cell-type-specific expression at the pituitary level similar to mammals, RT-PCR coupled with laser capture microdissection (LCM) of immuno-identified carp somatotrophs, lactotrophs, and gonadotrophs was also performed. In cytospin preparation of carp pituitary cells, the respective cell types were identified by immunostaining with antisera for carp GH (1:10,000), PRL (1:5,000), and LH $(1: 5,000)$ using a Vectastain $\mathrm{ABC}$ staining kit (Vector Laboratories, Burlingame, CA, USA) and isolated by LCM using a PixCell-II Cell Isolation System (Arcturus Engineering, Mountain View, CA, USA) (50). The target cells captured ( 250 cells per sample) were subjected to DNase I digestion and RT followed by PCR using the same conditions with cycle number extended to 45 cycles with primers for follistatin as described in preceding section for tissue expression profiling. In this experiment, RT-PCR with RT sample prepared from mixed populations of pituitary cells was used as the positive control and PCR for $\beta$ actin expression was used as the internal control.

\section{Protein Expression and Functional Testing of Carp Follistatin}

To confirm that the newly cloned cDNA encodes target protein with bioactivity, expression of grass carp follistatin was performed in $\mathrm{CHO}$ cells. In this case, the open reading frame (ORF) of carp follistatin without $5^{\prime} / 3^{\prime}$ untranslated region (UTR) was PCR isolated and subcloned into the eukaryotic expression vector pcDNA3.1. Using lipofectamine (Invitrogen), the vector was transfected into $\mathrm{CHO}$ cells cultured in $35 \mathrm{~mm}$ dish with a seeding density of $0.5 \times 10^{6}$ cells/dish. After a 6-h transfection in OPTI-MEM medium, the culture medium was replaced with DMEM medium supplemented with $10 \%$ FBS and the cell culture was maintained for 3 days under $5 \% \mathrm{CO}_{2}$ and saturated humidity prior to the collection of conditioned medium containing follistatin released from $\mathrm{CHO}$ cells. To test for the functionality of follistatin expressed, $\alpha \mathrm{T} 3$ cells with activin receptor expression (51) were maintained in DMEM medium in 24-well plates with 
a seeding density of $0.1 \times 10^{6}$ cells/well and transfected for $6 \mathrm{~h}$ with lipofectamine in the presence of $0.2 \mu \mathrm{g} /$ well of the firefly luciferase-expressing activin reporter pAR3-Lux (52), $0.05 \mu \mathrm{g} /$ well FAST-2 expression vector (as a co-factor for activin induction), and $0.02 \mu \mathrm{g} /$ well RL-TK.Luc (a renilla luciferase-expressing vector as internal control). After transfection, the cells were incubated for $18 \mathrm{~h}$ for recovery followed by drug treatment for $24 \mathrm{~h}$ with activin $\mathrm{A}(10 \mathrm{ng} / \mathrm{ml})$ and $\mathrm{B}(10 \mathrm{ng} / \mathrm{ml})$, respectively. To test the effect of follistatin in neutralizing activin's actions, follistatin co-treatment by adding $200 \mu 1$ volume of the conditioned medium with carp follistatin was performed in $\alpha \mathrm{T} 3$ cells in the presence of activin A and B, respectively. After treatment, the cells were lysed with passive lysis buffer (Promega, Madison, WI, USA) and the lysate prepared was subjected to measurement of firefly and renilla luciferase activities using a Dual-Glo ${ }^{\mathrm{TM}}$ Luciferase Assay (Promega).

\section{Follistatin and Activin mRNA Expression in Grass Carp Pituitary Cells}

Grass carp pituitary cells was prepared by trypsin/DNase digestion method (38) and seeded at a density of $2.5 \times 10^{6}$ cell/well in polyD-lysine precoated 24-well plates. After overnight incubation to allow for recovery from enzyme digestion, static incubation with activin $\mathrm{A}$, activin $\mathrm{B}$, follistatin, $\mathrm{DA}$, and its non-selective agonist APO or its D1-/D2-specific agonists/antagonists was performed for the duration as indicated for individual experiments to study their effects on follistatin, activin $\beta \mathrm{A}$, and activin $\beta \mathrm{B}$ mRNA expression at the pituitary level. To shed light on the role of follistatin on GH regulation by activin, parallel studies were also conducted with activin A and B induction with/without follistatin co-treatment to examine their effects on GH mRNA expression. To confirm that DA by acting through D1 receptor can play a role in follistatin expression at the somotroph level, carp somatotrophs (86-92\% pure) were enriched from mixed populations of pituitary cells by Percoll density gradient centrifugation (53) and used in the testing of follistatin mRNA expression with D1 activation by the D1 agonist SKF77434 in the presence or absence of activin A, activin B, or GH co-treatment. In these experiments, total RNA was isolated with Trizol (Sigma-Alrich) after drug treatment, digested with DNAse I and reversely transcribed into RT samples for subsequent real-time PCR for follistatin, activin $\beta \mathrm{A}$, activin $\beta \mathrm{B}$, and/or $\mathrm{GH}$ mRNA measurement. For individual real-time PCR assays, quantitative PCR with primers for the respective gene targets was conducted in a RotorGene 6000 Realtime PCR System (Corbett, NSW, Australia) using a LightCycler ${ }^{\circledR}$ 480 SYBR Green I Master Kit (Roche, Basel, Switzerland). For real-time PCR of follistatin, gene-specific primers for carp follistatin (5'ATGCAAAGGGCACCCGGATCT3' and 5'ATCGCATGACTTGGCCTTGATG3', producing a 292 bp PCR product with $T m$ value at $92^{\circ} \mathrm{C}$ ) were used for quantitative PCR with serial dilutions of plasmid DNA carrying the ORF of follistatin as the standards for data calibration. $\mathrm{PCR}$ reactions were conducted with denaturation at $95^{\circ} \mathrm{C}$ for $30 \mathrm{~s}$, annealing at $56^{\circ} \mathrm{C}$ for $30 \mathrm{~s}$, and extension at $72^{\circ} \mathrm{C}$ for $30 \mathrm{~s}$ for a total of 32 cycles and PCR signals for follistation expression were recorded by the end of individual cycles with acquiring temperature at $88^{\circ} \mathrm{C}$. For the measurement of activin $\beta \mathrm{A}$, activin $\beta \mathrm{B}$, and GH mRNA expression, real-time PCR for the respective gene targets was conducted as described previously (42). In our studies, the authenticity of PCR products was routinely monitored by melting curve analysis after the real-time PCR assays and parallel measurement of $18 \mathrm{~S}$ RNA expression was used as the internal control.

\section{Data Normalization and Statistical Analysis}

For expression studies of carp follistatin, the raw data for light emission caused by luciferase activity were registered in terms of relative light unit (in "RLU”). For normalization of potential variations in transfection efficiency between wells, the RLU data for firefly luciferase activity were normalized as a ratio of renilla luciferase activity detected in the same sample (referred to as "LUC activity ratio"). The normalized data were then expressed as a percentage of the mean value in the control group (as "\%Ctrl") and used for subsequent statistical analysis. For real-time PCR of target gene expression in carp pituitary cells, standard curves constructed with the respective plasmid DNA standards with a dynamic range of $\geq 10^{5}$, amplification efficiency $\geq 98 \%$, and correlation coefficient $\geq 0.95$ were used for data calibration under the unsupervised mode with RotorGene Q software 1.7 (Corbett). Since the levels of $18 \mathrm{~S}$ RNA expressed in carp pituitary cells did not exhibit significant changes with drug treatment in our experiments, the raw data for target transcripts (in femtomole target detected per $10^{6}$ cells) were transformed as a percentage of the mean value in the control group without drug treatment (as “\%Ctrl"). Data presented (mean \pm SEM) are pooled results from four to six separate experiments $(N=4-6)$ and were analyzed with one-way (for dose dependence and interaction studies) or two-way ANOVA (for time course) followed by Newman-Keuls multiple comparison test. Differences between experimental groups were considered as significant at $P<0.05$.

\section{RESULTS}

\section{Molecular Cloning and Structural Analysis of Grass Carp Follistatin}

Using $5^{\prime} / 3^{\prime}$ RACE, the full-length cDNA for grass carp follistatin (GenBank Accession No DQ340765) was cloned. The cDNA is $1,307 \mathrm{bp}$ in size composed of a 72 bp 5'UTR, 266 bp 3'UTR, and 966 bp ORF encoding a 322 a.a. follistatin precursor with deduced MW of $\sim 35.6 \mathrm{kDa}$ (Figure S1 in Supplementary Material). Based on phylogenetic analysis using neighbor-joining method with MEGA 6.0, the newly cloned cDNA could be clustered into the clade of fish follistatin and closely related to follistatin sequences reported in other members of carp family including goldfish and zebrafish (Figure 1A). Within the $3^{\prime} \mathrm{UTR}$, four polyadenylation signals (AAGAAA, ATTAAA, and two AATGAA) could be noted in close proximity/upstream region of the poly(A) tail. Based on structural analysis using SignalP 3.0 (http://cbs.dtu.dk/services/ SignalP), a signal peptide with the size of 33 a.a. was identified in the N-terminal of the deduced protein of carp follistatin precursor. By sequence alignment with follistatin proteins reported in other species (Figure S2 in Supplementary Material), the four 
A

$\underline{\text { Phylogenetic Analysis }}$

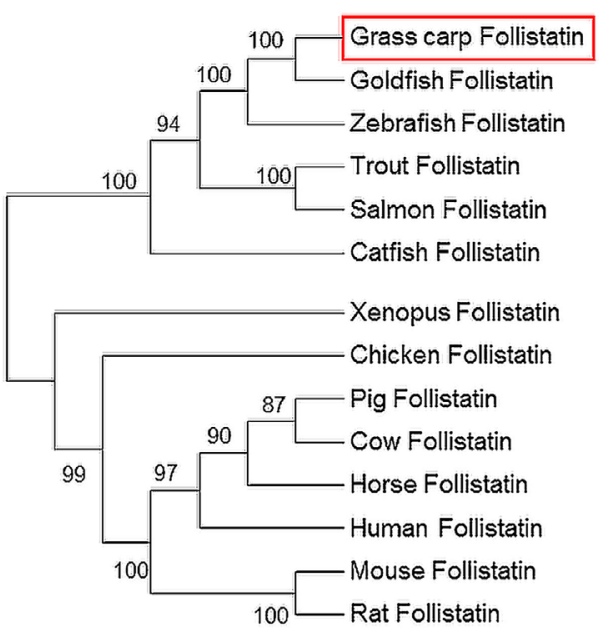

C

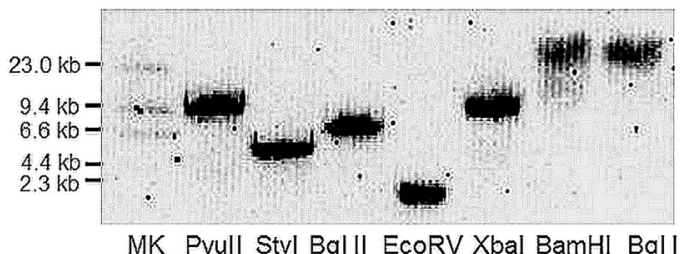

E

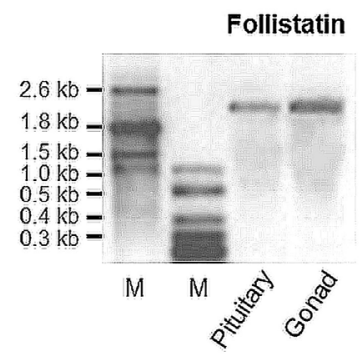

\section{Northern Blot}

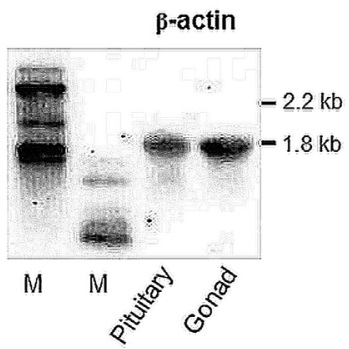

B

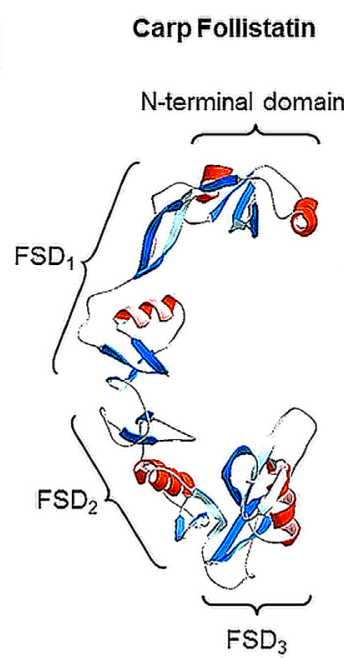

D

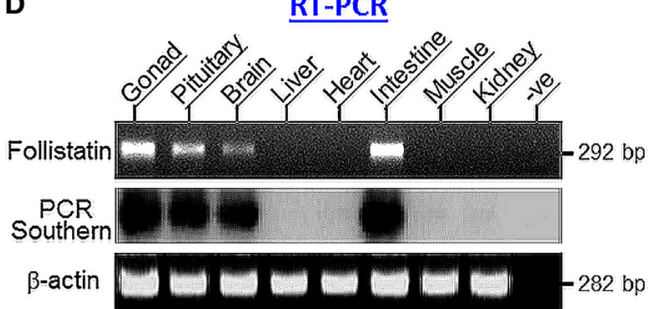

Human Follistatin

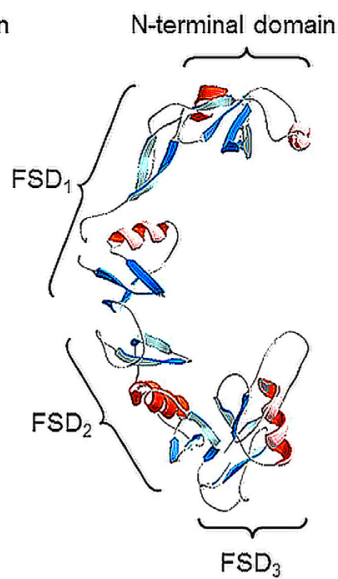

RT-PCR

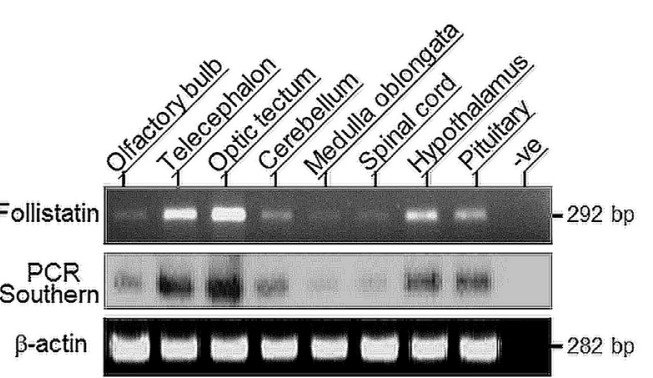

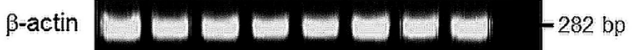

FIGURE 1 | Sequence analysis, gene copy number, and tissue expression of grass carp follistatin. (A) Phylogenetic analysis of carp follistatin cDNA with corresponding sequences reported in other species using neighbor-joining method with MEGA 6.0. The numbers presented with the guide tree are the percentage of bootstrap values based on a 1,000 bootstraps. (B) 3D protein modeling of carp follistatin using SWISS-MODEL and DeepView with the crystal structure of human follistatin as the template. The regions in red and blue represent the helical motifs and $\beta$ sheet structures, respectively, within the N-terminal and FSD ${ }_{1-3}$ domains. The four structural domains can be clustered into a "concave" structure, which is known to be essential for activin binding. (C) Gene copy number for carp follistatin deduced by genomic Southern. Southern blot was conducted with a DIG-labeled probe for follistatin in carp genomic DNA with prior digestion of restriction enzymes as indicated. (D) Tissue expression of follistatin in grass carp. Total RNA was isolated from selected tissues and brain areas as indicated and subjected to RT-PCR with primers specific for follistatin. The authenticity of PCR product was confirmed by PCR Southern with DIG-labeled probe for follistatin with parallel PCR for $\beta$ actin as internal control. (E) Characterization of follistatin transcript in the carp pituitary. Total RNA was isolated from the carp pituitary, resolved in 1\% agarose gel and subjected to Northern blot with DIG-labeled probe for follistatin. In this experiment, total RNA prepared form the gonad was used as a positive control and parallel blotting for $\beta$ actin transcript was used as the internal control (M: size markers for RNA transcripts).

structural domains in the carp follistatin, namely the N-terminal domain followed by $\mathrm{FSD}_{1}$ (with a lysine-rich proteoglycanbinding sequence), $\mathrm{FSD}_{2}$, and $\mathrm{FSD}_{3}$ domains, as well as the 36 cysteine residues spreading within these four structural motifs were found to be highly conserved. Interestingly, the C-terminal domain reported in tetrapod species appeared to be missing in fish models. By comparing the protein sequences of follistatin, the sequence homology is $>90 \%$ for fish species of the carp family (94-96\% vs the sequences for goldfish and zebrafish) but the homology level is notably reduced when compared with the 
follistatin sequences of other fish models ( $71 \%$ vs the sequence in catfish) or tetrapods (70-74\% for the sequences from amphibian to mammals). Despite the reduced level of sequence homology (only $71 \%$ vs the sequence in human), the $3 \mathrm{D}$ protein model deduced from carp follistatin, especially in the spatial orientation of helical motifs and $\beta$ sheets in the N-terminal and FSD $_{1-3}$ domains, was found to be highly comparable, if not identical to the corresponding structures in human follisatin (Figure 1B). Of note, the C-terminal domain forming the C-terminal tail of follistatin in tetrapods was not found in the corresponding region in carp model.

\section{Gene Copy Number and Tissue Expression of Carp Follistatin}

To deduce the copy number of follistatin gene in carp genome, Southern blot was conducted in genomic DNA isolated from whole blood of grass carp. As shown in Figure 1C, a single band was detected in DNA samples predigested with Pvu II, Sty I, Bgl II, Ecor V, Xba I, BamH I, and Bgl I after hybridization with DIG-labeled probe for carp follistatin, confirming that the newly cloned follistatin is a single-copy gene in carp model. To shed light on tissue distribution of follistatin expression, RT-PCR was performed in selected tissues and brain areas in grass carp (Figure 1D). In this study, the PCR cycle number was fixed at 35 cycles, as it is in the mid-log phase of PCR amplification of follistatin. In our tissue expression profiling, follistatin PCR signals were detected at high levels in the gonad and intestine and with notable level in the brain and pituitary, but not in the liver, heart, muscle, and kidney. In the brain, follistatin was found to be ubiquitously expressed in different areas, with high levels in the telencephalon and optic tectum, to a lower extent in the hypothalamus, cerebellum, and pituitary, and at very low levels in the olfactory bulbs, medulla oblongata, and spinal cord. The lack of follistatin signals in the liver, heart, muscle, and kidney could not be due to RNA degradation during sample preparation, as $\beta$ actin signal (as internal control) was consistently detected in all the samples examined.

Given that multiple transcripts of follistatin giving rise to two major isoforms of follistatin, follistatin-315 and follistatin-288, have been reported in mammals (54), the size and form(s) of follistatin mRNA expressed were also characterized in the carp pituitary using Northern blot with parallel study of the gonad as a positive control (Figure 1E). In this case, a single transcript for follistatin with $2.2 \mathrm{~kb}$ in size was detected both in the pituitary as well as in the gonad. To further examine protein expression of activin/follistatin system at pituitary level, LC/MS/MS was performed in trypsin-digested lysate prepared from the carp pituitary. Based on the mass spectra obtained, peptide fragments originated from carp follistatin (with protein coverage of $57.8 \%$, Figure S3 in Supplementary Material), activin $\beta \mathrm{A}$ (with protein coverage of $56.9 \%$, Figure S4 in Supplementary Material), and activin $\beta \mathrm{B}$ (with protein coverage of $59.4 \%$, Figure S5 in Supplementary Material) could all be identified in this pituitary sample, indicating that the major components of activin/follistatin system are also expressed in the carp pituitary at protein level.

\section{Protein Expression and Functional Testing of Carp Follistatin}

To confirm that the newly cloned cDNA indeed encodes follistatin with the ability to block activn's actions, functional expression was conducted in $\mathrm{CHO}$ cells after transfection with the expression vector for carp follistatin. After 3-day culture to allow for the accumulation of carp follistatin released from $\mathrm{CHO}$ cells, the conditioned medium was harvested and their bioactivity was tested in $\alpha \mathrm{T} 3$ cells transfected with the luciferaseexpressing activin reporter pAR3-Lux (52) carrying tandem repeats of activin-responsive elements in its $5^{\prime}$ promoter. The $\alpha \mathrm{T} 3$ cells were used as it is a pituitary cell line with activin receptor expression and known to be highly responsive to activin stimulation (51). In our study, treatment with human activin A $(10 \mathrm{ng} / \mathrm{ml})$ and B $(10 \mathrm{ng} / \mathrm{ml})$ were both effective in elevating luciferase activity expressed in $\alpha \mathrm{T} 3$ cells and these stimulatory effects could be abolished by co-treatment with human follistatin (100 ng/ml, Figure 2A), implying that our assay system is fully functional in probing follistatin inhibition on activin actions. In parallel experiment with $\alpha \mathrm{T} 3$ cells transfected with pAR3-Lux, incubation with conditioned medium containing carp follistatin released from $\mathrm{CHO}$ cells could also trigger a total blockade on the stimulatory effects of activn A $(10 \mathrm{ng} / \mathrm{m})$ and B $(10 \mathrm{ng} / \mathrm{ml})$ on luciferase activity expression (Figure 2B). However, similar treatment with conditioned medium harvested from $\mathrm{CHO}$ cells transfected with the blank vector (used as negative control) was found to have no effects on luciferase activity induced by activin $A$ and $B$, respectively.

\section{Regulation of Activin/Follistatin System in Carp Pituitary Cells}

To shed light on autoregulation of activin/follistatin system in the carp pituitary, the effects of activin treatment on follistatin and activin gene expression were tested in primary culture of grass carp pituitary cells. In this case, static incubation with activin A $(10 \mathrm{ng} / \mathrm{ml})$ and $\mathrm{B}(10 \mathrm{ng} / \mathrm{ml})$ were both effective in inducing follistatin mRNA expression in a time-dependent manner with peak responses at $24 \mathrm{~h}$ (Figure 3A). By fixing the duration of drug treatment at $24 \mathrm{~h}$, increasing doses of activin A (0.3-30 ng/ $\mathrm{ml})$ and $\mathrm{B}(0.3-30 \mathrm{ng} / \mathrm{ml})$ could also elevate follistatin mRNA levels in a concentration-related fashion (Figure 3B) but with no corresponding changes in activin $\beta \mathrm{A}$ and $\beta \mathrm{B}$ transcript expression (Figure 3C). Given that follistatin produced locally is known to bind and neutralize activin's actions at the pituitary level (13), removal of endogenous activin by static incubation with follistatin $(10-1,000 \mathrm{ng} / \mathrm{ml})$ was also performed in carp pituitary cells. As shown in Figures 4A,B, follistatin treatment could dose-dependently suppress follistatin mRNA levels but with no effects on activin $\beta \mathrm{A}$ and $\beta \mathrm{B}$ gene expression. In parallel experiment, co-treatment with follistatin $(100 \mathrm{ng} / \mathrm{ml})$ was also effective in blocking follistatin mRNA expression induced by activin $\mathrm{A}(10 \mathrm{ng} / \mathrm{ml})$ and $\mathrm{B}(10 \mathrm{ng} / \mathrm{ml})$, respectively (Figure 4A, inset). In the same study, GH mRNA level could be up-regulated by follistatin but the inhibitory effects on $\mathrm{GH}$ gene expression induced by activin A and B were also reverted/negated by follistatin co-treatment in carp pituitary cells (Figure 4C). 


\section{A

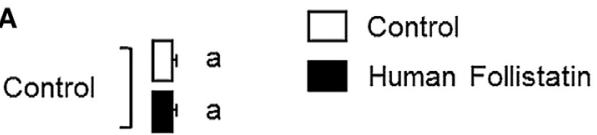

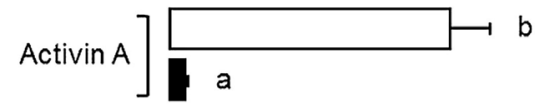

Activin B]

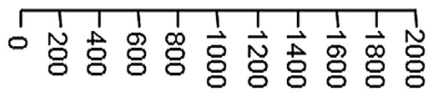

LUC activity ratio (\%Ctrl)

B
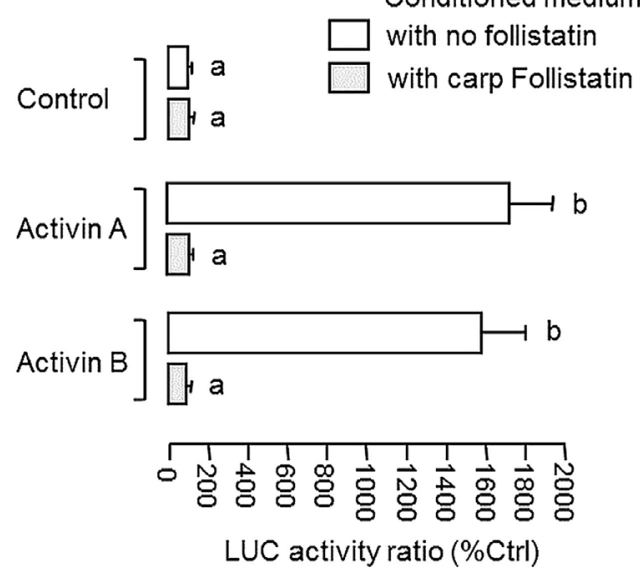

FIGURE 2 | Functional characterization of carp follistatin in $\alpha \mathrm{T} 3$ cells. (A) Validation of follistatin blocking of activin's action in $\alpha \mathrm{T} 3$ cells with pAR3-Lux transfection. In this experiment, $\alpha$ T3 cells were transfected with the pAR3-Lux reporter with 5'promoter carrying tandem repeats of activinresponsive elements and challenged for $24 \mathrm{~h}$ with human activin $\mathrm{A}(10 \mathrm{ng} / \mathrm{ml})$ and $B(10 \mathrm{ng} / \mathrm{ml})$, respectively. In treatment group, activin $A$ and $B$ induction were conducted in the presence of human follistatin (100 ng/ml). (B) Grass carp follistatiin on activin-induced pAR3-Lux reporter activity expressed in $\alpha \mathrm{T} 3$ cells. Conditioned medium obtained from $\mathrm{CHO}$ cells transfected with the expression vector for carp follistatin was used as the source of follistatin of carp origin. For functional testing of carp follistatin, $\alpha \mathrm{T} 3$ cells transfected with pAR3-Lux were challenged for $24 \mathrm{~h}$ with activin $\mathrm{A}(10 \mathrm{ng} / \mathrm{ml})$ and $\mathrm{B}(10 \mathrm{ng} / \mathrm{ml})$ in the presence of the conditioned medium containing carp follistatin. Parallel incubation with conditioned medium harvested from $\mathrm{CHO}$ cells transfected with the blank vector pcDNA3.1 was used as the control treatment. In these experiments, cell lysate was prepared from $\alpha \mathrm{T} 3$ cells after activin treatment (with/without follistatin) and used for luciferase activity measurement with a Dual-Glo ${ }^{\circledR}$ assay kit. Data presented are expressed as mean $\pm \operatorname{SEM}(N=6)$ and the groups denoted by different letters represent a significant difference at $P<0.05$ (ANOVA followed by Newman-Keuls test).

Since dopaminergic regulation of pituitary functions is well-documented (55), it raises the possibility that the activin/ follistatin system in the carp pituitary may also serve as a regulatory target for dopaminergic input form the hypothalamus. To test the idea, carp pituitary cells were challenged for $24 \mathrm{~h}$ with DA $(1 \mu \mathrm{M})$ or its non-selective agonist APO (1-1,000 nM). In both cases, dopaminergic activation was effective in inhibiting follistatin mRNA levels (Figure 5A) without affecting activin $\beta A$ and $\beta B$ gene expression (Figure $5 B$ ). To further investigate the receptor specificity for DA action, carp pituitary cells were treated for $24 \mathrm{~h}$ with increasing levels $(1-1,000 \mathrm{nM})$ of the DA D1 agonist SKF77434 and D2 agonist Ly171555, respectively (Figure 5C). In this study, dopaminergic inhibition on follistatin mRNA expression was mimicked in a dose-dependent manner by the D1 agonist SK77434 but not the D2 agonist Ly171555. In agreement with these results, the drop in follistatin mRNA level induced by DA $(1 \mu \mathrm{M})$ could also be blocked by co-treatment with the D1 antagonist SKF83566 (5 $\mu \mathrm{M})$ but not D2 antagonist sulpiride $(5 \mu \mathrm{M})$ (Figure 5D). To examine DA D1 interaction with activin on follistatin regulation at pituitary level, carp pituitary cells were challenged for $24 \mathrm{~h}$ with activin A $(10 \mathrm{ng} / \mathrm{ml})$ and $B(10 \mathrm{ng} / \mathrm{ml})$ in the presence of the D1 agonist SKF77434 $(1 \mu \mathrm{M})$. As shown in Figure 6A, follistatin mRNA expression induced by activin A and B could be notably suppressed by SKF77434 co-treatment. In our recent study, follistatin gene expression in the carp pituitary was found to be differentially regulated by $\mathrm{GH}$ and $\mathrm{LH}$, with stimulation by $\mathrm{GH}$ but inhibition by LH (42). Therefore, DA D1 interactions with the two hormones were also investigated (Figure 6B). In carp pituitary cells, follistatin mRNA level could be up-regulated by $\mathrm{GH}$ induction $(30 \mathrm{ng} / \mathrm{ml})$ but this stimulatory effect was significantly reduced by co-treatment with SKF77434 $(1 \mu \mathrm{M})$. The corresponding inhibition caused by hCG $(30 \mathrm{IU} / \mathrm{ml}$, used as a functional analog of $\mathrm{LH}$ ), however, was found to be not additive to that of SKF77434.

\section{Follistatin Expression and Regulation in Carp Somatotrophs}

Given that follistatin is known to express in the pituitary of mammals in a cell-type-specific manner, e.g., in rodents (13), the expression profile of follistatin in various cell types in the carp pituitary was also characterized using RT-PCR coupled to LCM isolation of carp somatotrophs ( $\mathrm{GH}$ cells), gonadotrophs (LH cells), and lactotrophs (PRL cells) identified by immunostaining with the respective antisera (Figure 7A). Similar to the result based on mixed populations of pituitary cells ("Mixed Pit cells"), the PCR signal for follistatin could also be detected in carp somatotrophs, gonadotrophs, and lactotrophs. These PCR signals could not be the result of genomic DNA contamination, as parallel PCR with RNA samples without (“-RT”, used as negative control) did not produce any PCR product in our study. To further examine follistatin regulation at somatotroph level, enriched fraction of carp somatotrophs (86-92\% pure) was prepared from mixed populations of carp pituitary cells using Percoll density gradient centrifugation (53). The remaining cells after somatotroph enrichment (designated as "somatotroph-deficient cells") were used as a parallel control for our experiments with carp somatotrophs (Figure 7B). In the two cell fractions prepared, follistatin mRNA levels could be up-regulated by 24 -h treatment with activin $\mathrm{A}(10 \mathrm{ng} / \mathrm{ml})$, activin $\mathrm{B}(10 \mathrm{ng} / \mathrm{ml})$, and $\mathrm{GH}(30 \mathrm{ng} /$ $\mathrm{ml})$, respectively, with much higher responses in enriched 

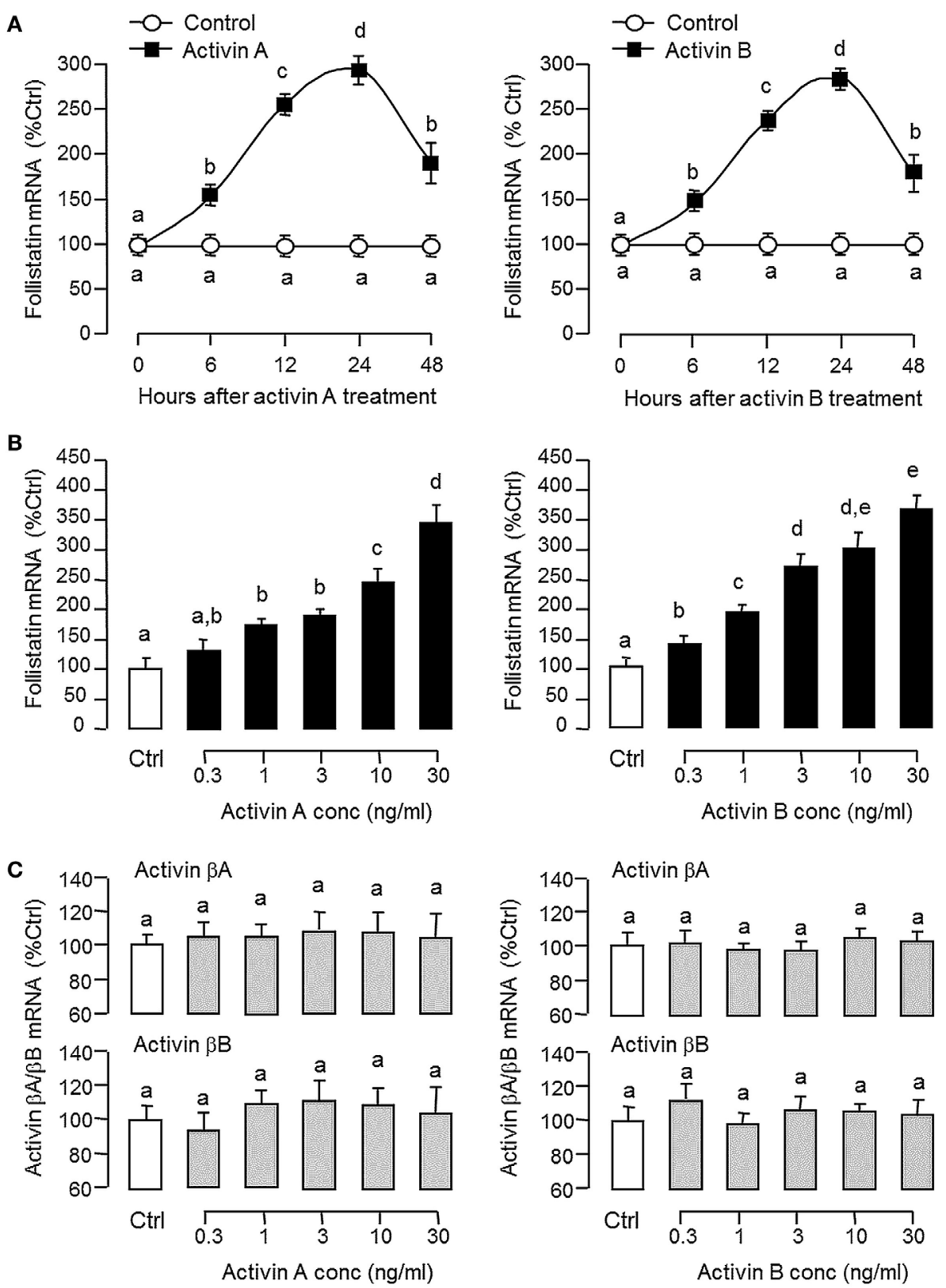

FIGURE 3 | Effects of activin A and B on follistatin, activin $\beta A$, and activin $\beta B$ expression in grass carp pituitary cells. (A) Time course and (B) dose dependence of activin-induced follistatin mRNA expression. (C) Dose dependence of activin treatment on activin $\beta A$ and $\beta B$ mRNA expression. In time course experiment, pituitary cells were incubated with activin A (10 ng/ml) or activin B (10 ng/ml) for the duration as indicated up to $48 \mathrm{~h}$. To test for dose dependence, the duration of drug treatment was fixed at $24 \mathrm{~h}$ with pituitary cells challenged with increasing levels of activin $\mathrm{A}$ or $\mathrm{B}$, respectively. After activin treatment, total RNA was isolated and used for real-time PCR of follistatin, activin $\beta A$, and activin $\beta B$ mRNA, respectively. Data presented are pooled from four separate experiments ( $N=4$ ) and the groups denoted by different letters represent a significant different at $P<0.05$ (ANOVA followed by Newman-Keuls test).

somatotrophs (23-28-fold increase vs basal) compared with somatotroph-deficient cell fraction (only 2.2-3.0-fold increase vs basal). Similar to the results based on mixed populations of pituitary cells (Figure 6), the stimulatory effects on follistatin gene expression caused by activin and $\mathrm{GH}$ detected in the two cell fractions were notably suppressed by the D1 agonist SKF77434 (1 $\mu \mathrm{M})$.

\section{DISCUSSION}

Activin/follistatin system is known to play a role in pituitary functions, e.g., for FSH (13), GH (28), and PRL secretion/gene expression (29) and its involvement in FSH regulation is also wellconserved in fish species, e.g., goldfish (31), zebrafish (32), and European eel (33). Unlike the extensive studies in mammals, not 

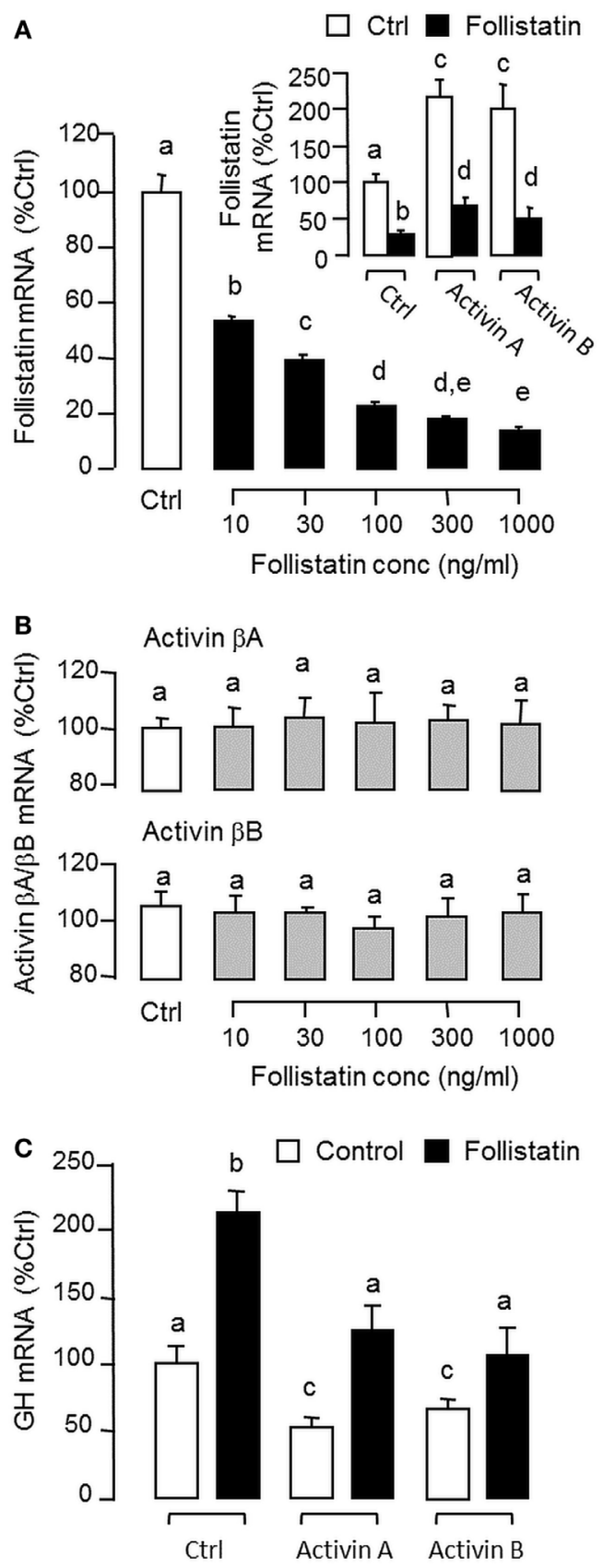

FIGURE 4 | Removal of endogenous activin by follistatin on follistatin, activin $\beta \mathrm{A}$, and activin $\beta \mathrm{B}$ expression in grass carp pituitary cells. (A) Effects of follistatin treatment on basal and activin-induced follistatin mRNA expression. (B) Effects of follistatin treatment on activin $\beta A$ and $\beta B$ mRNA expression. (C) Effects of follistatin treatment on basal and activin-induced growth hormone $(\mathrm{GH})$ mRNA expression. To examine the effect on basal expression of follistatin mRNA, pituitary cells were treated for $24 \mathrm{~h}$ with increasing doses of follistatin as indicated. To test the effects of follistatin on activin modulation of follistatin and $\mathrm{GH}$ gene expression, pituitary cells were challenged for $24 \mathrm{~h}$ with activin $\mathrm{A}(10 \mathrm{ng} / \mathrm{ml})$ or $\mathrm{B}(10 \mathrm{ng} / \mathrm{ml})$ with/without the co-treatment of follistatin $(100 \mathrm{ng} / \mathrm{ml})$. In these experiments, total RNA was isolated after drug treatment and subjected to real-time PCR of follistatin, activin $\beta A$, activin $\beta B$, and $\mathrm{GH}$ mRNA, respectively. Data presented are pooled from four separate experiments $(N=4)$ and the groups denoted by different letters represent a significant different at $P<0.05$. much is known for the pituitary regulation of activin/follistatin system in fish models. Recently, using grass carp as a representative for Cyprinid species, we have shown that local production of $\mathrm{GH}$ could induce activin $\beta \mathrm{A}$ and $\beta \mathrm{B}$ expression in carp pituitary cells and subsequent production of activin, interestingly, was found to inhibit GH secretion and GH gene expression (42), implying that activin can exert a negative feedback on $\mathrm{GH}$ regulation in carp pituitary. To further characterize the role of activin/ follistatin system in $\mathrm{GH}$ regulation in carp species, grass carp follistatin was cloned and confirmed to be a single-copy gene in carp genome. Based on phylogenetic analysis and sequence alignment, the newly cloned cDNA was shown to be an ortholog of follistatin in fish species and closely related to the corresponding sequences in goldfish and zebrafish. As shown by 3D protein modeling, the four structural domains of carp follistatin, namely the $\mathrm{N}$-terminal domain and $\mathrm{FSD}_{1-3}$ domains, can be clustered into a concave structure, which is known to be essential for activin binding (56), and the spacing and orientation of helical motifs and $\beta$ sheets within these structural domains are also highly comparable if not identical to the human counterparts, implying that the $3 \mathrm{D}$ protein structure of follistatin, especially the "core structure" for activin binding, is highly conserved from fish to mammals. Of note, the C-terminal tail reported in the follistatin of tetrapods was found to be missing in carp follistatin. In mammals, two forms of follistatin, follistatin-315 (with C-terminal tail and mainly found in blood) and follistatin-288 (without C-terminal tail and mainly found at tissue level), have been identified and known to be formed by alternative splicing of exon 6 encoding the C-terminal domain (54). The C-terminal tail, which is Glu-rich and highly acidic, can interact with the proteoglycan-binding motif within $\mathrm{FSD}_{1}$ domain and reduce follistatin binding to the heparin chain of cell surface proteoglycan, and presumably, can allow for the release of follistain-315 into systemic circulation (57). At the pituitary level (e.g., in rat), follistatin-288 was found to be more potent than follistatin-315 in inhibiting FSH secretion (58), implying that the C-terminal tail can also affect follistatin function mediated by activin binding. In our study, the lack of C-terminal tail in carp follistation suggests that it is the functional equivalence of follistatin-288 and may exert its effects mainly at tissue level but not as an endocrine factor.

Regarding the autocrine/paracrine actions of follistatin, it is well-documented that follistatin produced locally can bind activin with high affinity and nullify/neutralize its biological effects by preventing its binding to activin receptors (2). In our study with functional testing in $\alpha \mathrm{T} 3$ cells, grass carp follistatin expressed in $\mathrm{CHO}$ cells was shown to block the stimulation of activin A and B on target promoter with tandem repeats of activin-responsive elements originated from the human Mix2 promoter (52), implying that the newly cloned cDNA indeed encodes functional protein which can serve as a negative regulator for activin's actions. In mammals, follistatin is expressed at high level in the gonad and plays a role in folliculogenesis (9), spermatogenesis (10), and sex steroid production (59). Besides the gonad, extragonadal expression of follistatin has also been reported, e.g., in the brain, pituitary, kidney, and heart $(60,61)$. In grass carp, high levels of follistatin expression could be located in the gonad and intestine and to a lower extent in various brain areas and pituitary. In general, 

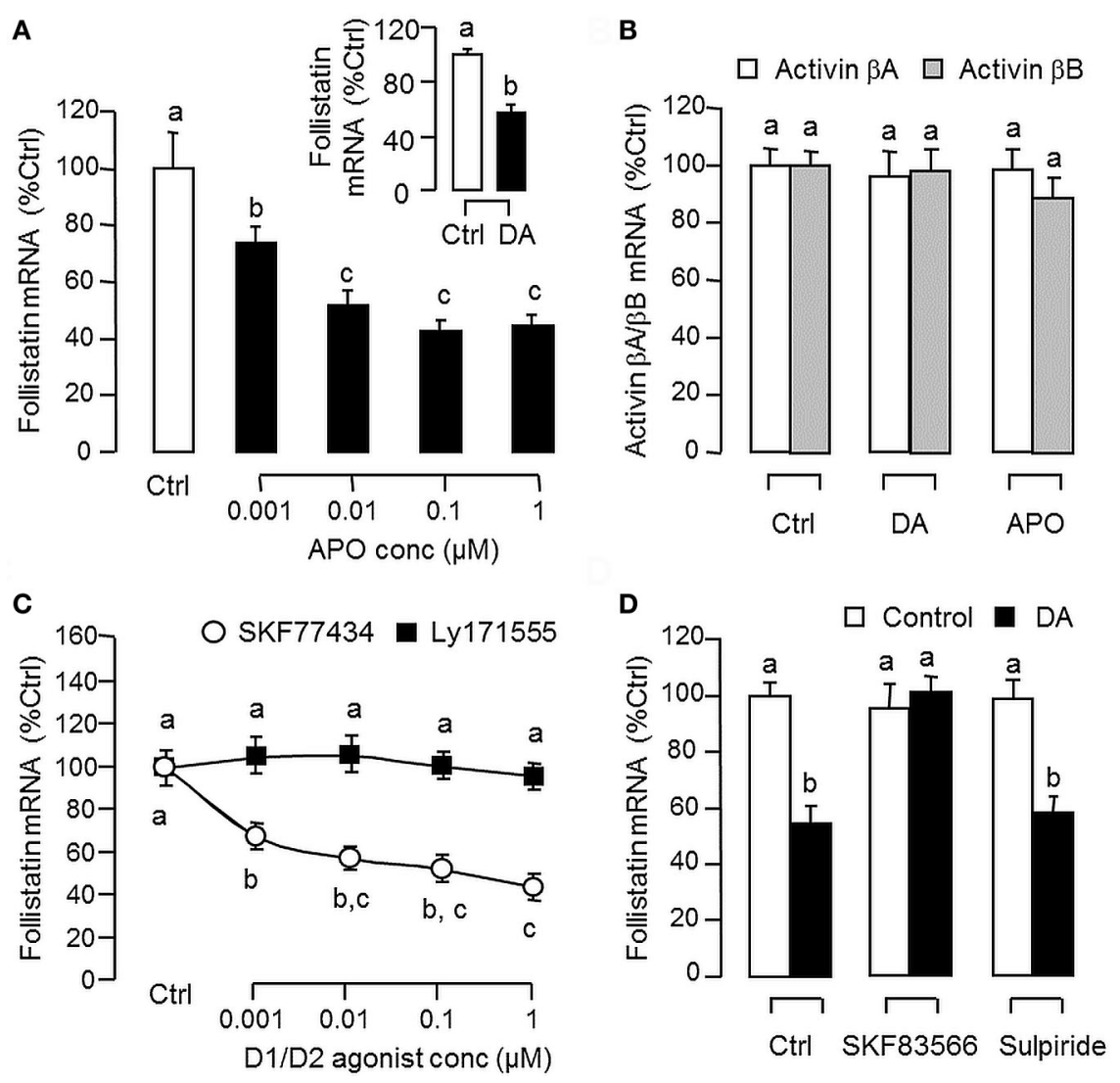

FIGURE 5 | Dopaminergic regulation of follistatin and activin expression in carp pituitary cells. (A) Effects of dopamine (DA) and its non-selective agonist apomorphine (APO) on follistatin mRNA expression. Pituitary cells were treated for $24 \mathrm{~h}$ with increasing doses of APO (0.001-1 $\mu \mathrm{M})$ or with a single dose of DA $(1 \mu \mathrm{M})$. (B) Effects of DA and APO on activin $\beta A$ and $\beta B$ mRNA expression. Pituitary cells were treated for $24 \mathrm{~h}$ with DA (1 $\mu \mathrm{M})$ or APO (1 $\mu \mathrm{M})$. (C) Effects of DA D1 and D2 agonists on follistatin mRNA expression. Pituitary cells were treated for $24 \mathrm{~h}$ with increasing doses of the DA D1 agonist SKF77434 or D2 agonist Ly171555 as indicated. (D) DA D1 and D2 antagonists on the inhibitory effect of DA on follistatin mRNA expression. Pituitary cells were challenged with DA (1 $\mu$ M) for $24 \mathrm{~h}$ in the presence or absence of the DA D1 antagonist SKF83566 $(5 \mu \mathrm{M})$ or D2 antagonist sulpiride $(5 \mu \mathrm{M})$. In these studies, total RNA was isolated after drug treatment and subjected to real-time PCR measurement for follistatin, activin $\beta A$, and activin $\beta \mathrm{B} m \mathrm{mNA}$, respectively. Data presented are pooled from four experiments ( $N=4$ ) and the groups denoted by different letters represent a significant different at $P<0.05$.

the pattern of follistatin expression in grass carp is comparable with that reported in other fish species, e.g., in goldfish (34). Despite a lack of information for testicular function of follistatin in fish models, high level of gonadal expression of follistatin in carp species is in agreement with the role of activin/follistatin system in folliculogenesis and oocyte maturation reported in fish ovary, e.g., in zebrafish $(30,62)$. The functional role of follistatin in the intestine is still unclear, although activin is known to be involved in wound healing and inflammation in gut epithelium (63) and follistatin expression in rat intestinal epithelial cells can be inhibited by PPAR $\gamma$ in mammalian models (64). Within the brain of grass carp, follistatin was found to be widely expressed and with high levels of signals detected in the telencephalon and optic tectum, to a lower extent in the hypothalamus and cerebellum, and at low levels in olfactory bulbs, medulla oblongata, and spinal cord. The biological relevance of follistatin in these brain areas has yet to be examined in fish model, but in rodents, activn and follistatin are known to be expressed in the brain and play a role in neuronal development in the hippocampus (65) and adult neurogenesis after brain injury (66). In chick embryo, follistatin is also involved in segmental patterning of the hindbrain development (67) suggesting that the activin/follistatin system may be an integral component for the process of neuron development and organization within the central nervous system.

Although the pituitary actions of activin/follistatin system is well-documented in mammals (see Introduction for details), the corresponding effects in the fish pituitary appear to be similar and yet distinct from that of the mammals. For examples, activin is known to exert a stimulatory action on FSH but with little/no effect on LH secretion/gene expression, especially in primary culture of rat pituitary cells (23). In pituitary cells from fish species, e.g., in goldfish (31), zebrafish (32), and more recently in European eel (33), activin treatment can exert differential effects on the two gonadotropins, with stimulation on FSH but inhibition on LH expression. Similar to mammals (e.g., in rat pituitary cells) (26), follistatin expression in fish pituitary cells can be up-regulated by activin (34), and the differential effects of activin on the two gonadotropins can be 

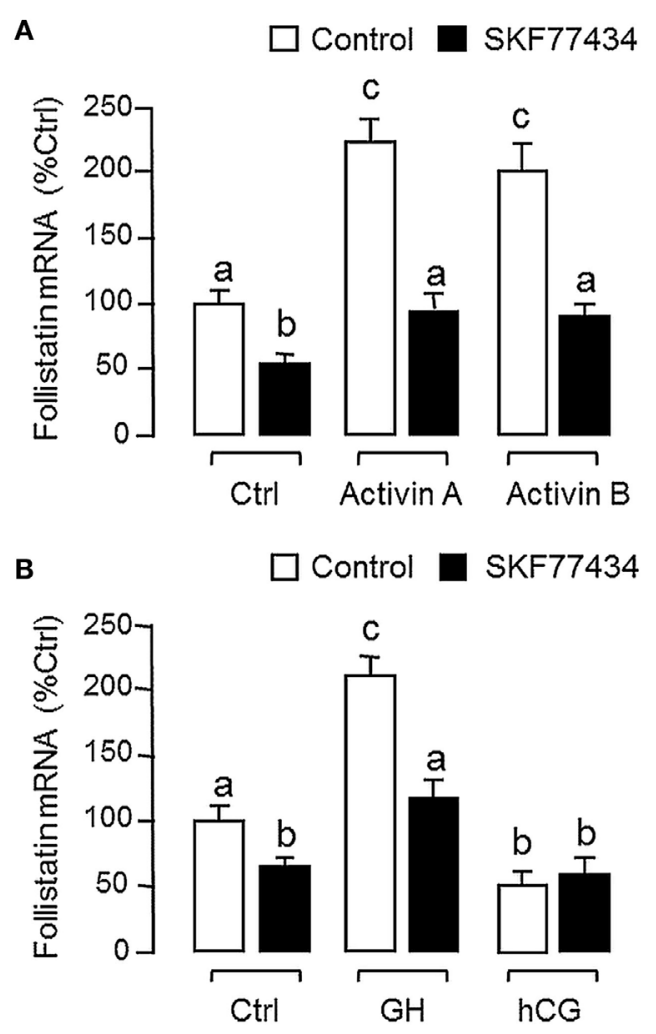

FIGURE 6 | Follistatin regulation by activin, growth hormone (GH), and human chorionic gonadotropin (hCG) and their interaction with dopaminergic D1 stimulation in grass carp pituitary cells. (A) Dopamine (DA) D1 activation on activin-induced follistatin mRNA expression. Pituitary cells were incubated for $24 \mathrm{~h}$ with activin $\mathrm{A}(10 \mathrm{ng} / \mathrm{ml})$ or $\mathrm{B}(10 \mathrm{ng} / \mathrm{ml})$ in the presence or absence of the D1 agonist SKF77434 (1 $\mu \mathrm{M})$. (B) DA D1 activation on the differential effects of $\mathrm{GH}$ and hCG on follistatin mRNA expression. Pituitary cells were exposed to $\mathrm{GH}(30 \mathrm{ng} / \mathrm{ml})$ or hCG $(30 \mathrm{IU} / \mathrm{ml})$ for $24 \mathrm{~h}$ with/without the co-treatment of the D1 agonist SKF77434 (1 $\mu \mathrm{M})$. After drug treatment, total RNA was isolated and subjected to real-time PCR for follistatin mRNA measurement. Data presented are pooled from four experiments $(N=4)$ and the groups denoted by different letters represent a significant different at $P<0.05$.

blocked by follistatin, e.g., in goldfish (35), suggesting that a local feedback of activin/follistatin system is present in the fish pituitary and contributes to gonadotropin regulation. In grass carp, together with activin $\beta A$ and $\beta B$ mRNA detected in our cell culture experiments, follistatin was found to be expressed at the pituitary level with a single transcript of $2.2 \mathrm{~kb}$ in size. Using LC/MS/MS, protein expression of follistatin, activin $\beta \mathrm{A}$, and activin $\beta \mathrm{B}$ was also confirmed in carp pituitary lysate, indicative of the presence of an activin/follistatin system in the carp pituitary. In the pituitary of mammals (e.g., in rat), activin is expressed mainly in gonadotrophs (22) while follistatin can be located in folliculo-stellate cells and to a lower extent in gonadotrophs (24). In our recent study using RT-PCR coupled with LCM isolation of immuno-identified pituitary cells, activin $\beta \mathrm{B}$, the dominant form of activin expressed in the carp pituitary, was shown to be highly expressed in gonadotrophs and with a lower level in lactotrophs but not in somatotrophs, whereas activin $\beta \mathrm{A}$ was expressed in pituitary cells other than the three cell types examined (42). In this study, using a similar approach, follistatin expression could be identified in carp gonadotrophs, lactotrophs, and somatotrophs, implying that individual components of activin/follistatin system are expressed in a cell-typespecific manner within the carp pituitary. In carp pituitary cells, follistatin mRNA expression could be up-regulated by activin $\mathrm{A}$ and $\mathrm{B}$, while the opposite was true by removing endogenous activin with follistatin. Besides, follistatin treatment also blocked follistatin gene expression induced by activin A and B. Of note, activin and follistatin were not effective in altering activin $\beta A$ and $\beta B$ mRNA levels at pituitary level, implying that follistatin may serve as a major regulatory target for the activin/follistatin system in carp species. In the carp pituitary, our recent study has revealed that (i) activin $\beta \mathrm{A}$ and $\beta \mathrm{B}$ expression could be induced by GH and (ii) activin A and B could suppress GH release and $\mathrm{GH}$ gene expression (42). In the current study, follistatin alone could elevate $\mathrm{GH}$ mRNA level in carp pituitary cells but the inhibitory effects of activin A and B on GH gene expression could be negated by follistatin co-treatment. These findings, as a whole, indicate that a local feedback via activin induction of follistatin also exists in carp pituitary and plays a role in $\mathrm{GH}$ regulation by activin/follistatin system in carp species.

In mammals, follistatin expression at pituitary level is known to be under the influence of hypothalamic factors. For examples, GnRH and PACAP can down-regulate FSH $\beta$ mRNA level by stimulating follistatin expression in rat gonadotrophs and L $\beta$ T2 cell line (68). However, similar study on hypothalamic regulation of pituitary activin/follistatin system is still lacking in fish models. In bony fish, the anterior pituitary is under the direct innervations of a preoptico-hypophyseal dopaminergic pathway, e.g., in goldfish (44) and rainbow trout (43). Our previous studies in goldfish also reveal that DA can induce GH secretion via activation of pituitary D1 receptor (45) with concurrent inhibition on $\mathrm{LH}$ release via $\mathrm{D} 2$ receptor activation (47). Given that DA D1 induction of GH release has also been demonstrated in carp pituitary cells (38) and local production of activin can modulate $\mathrm{GH}$ release and $\mathrm{GH}$ gene expression in carp pituitary (42), we speculate that dopaminergic input at the pituitary level may have an effect on activin/follistatin system related to GH regulation in carp model. This idea is supported by our findings that follistatin mRNA levels in carp pituitary cells could be down-regulated by DA. Apparently, the inhibitory effects observed were mediated by DA D1 receptor activation in the carp pituitary, as (i) down-regulation of follistatin mRNA levels could be mimicked by D1 but not D2 agonist and (ii) DA inhibition on follistatin gene expression was blocked by D1 antagonist but D2 antagonist was not effective in this regard. Since dopaminergic stimulation was not effective in altering activin $\beta A$ and $\beta B$ mRNA expression in carp pituitary cells, the possibility of D1 regulation of follistatin expression via modifications of activin production is unlikely. Of note, follistatin mRNA expression induced by activin A and B could be blocked by D1 agonist, suggesting that the local feedback of activn/follistatin system via activin-induced follistatin expression is also under the negative regulation by DA D1 action. At the pituitary level (e.g., rat), DA D2 activation has been reported to inhibit 
A

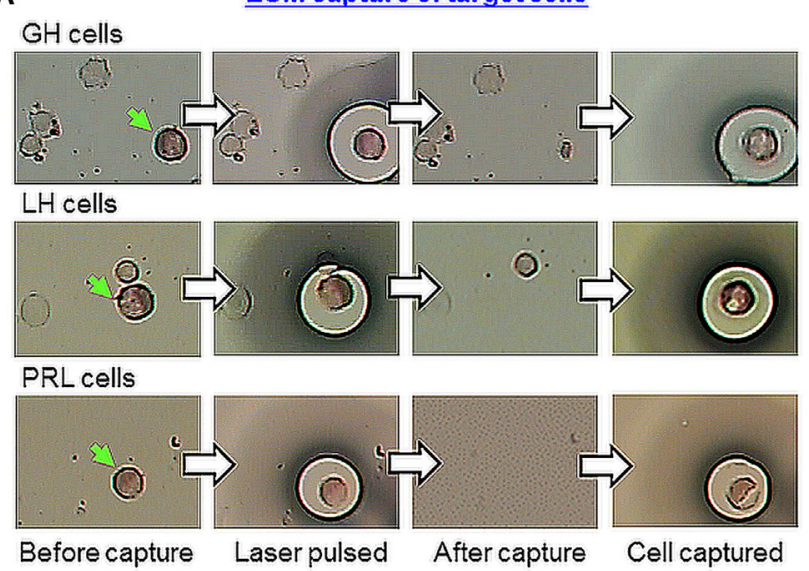

RT-PCR of LCM-isolated immunoidentified pituitary cells

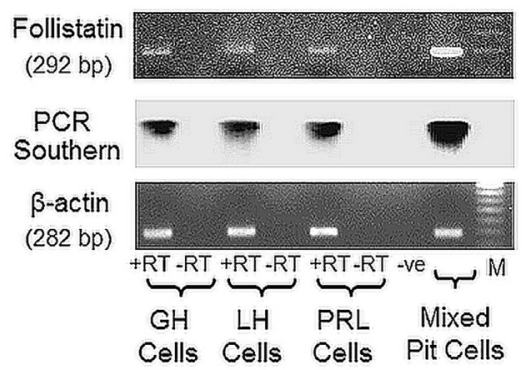

B
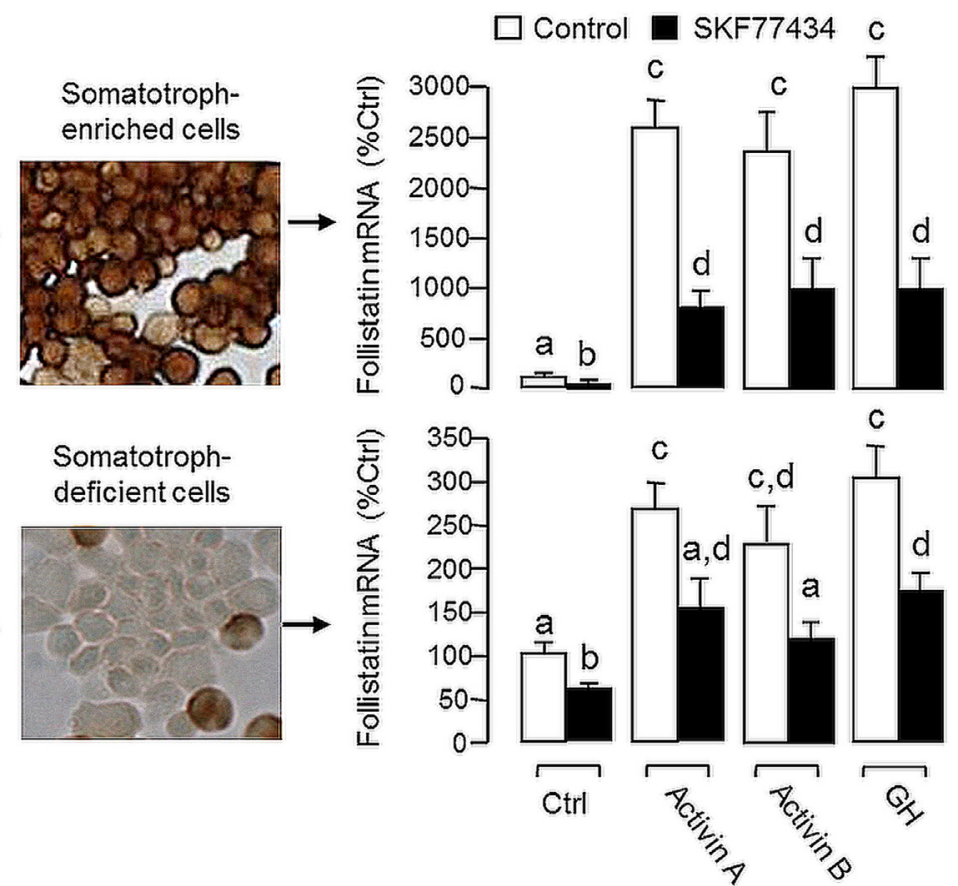

FIGURE 7 | Effects of dopamine (DA) D1 activation on follistatin expression induced by activin and growth hormone (GH) in carp somatotrophs. (A) Follistatin expression in carp somatotrophs (GH cells), lactotrophs [prolactin (PRL) cells], and gonadotrophs [luteinizing hormone (LH) cells]. The three cell types (marked by green arrows) were identified by immunostaining using antisera for carp $\mathrm{GH}, \mathrm{PRL}$, and LH, respectively, and isolated on HS caps using laser capture microdissection technique. After that, RT-PCR was performed on the cells captured ( 200 cells for individual cell types) using primers for follistatin. Mixed populations of pituitary cells were used as a positive control and RNA samples prepared with/without reverse transcription ( \pm RT) were used to control for potential contamination with genomic DNA. The authenticity of PCR product was confirmed by PCR Southern using DIG-labeled probe for carp follistatin and parallel PCR for $\beta$ actin mRNA was used as the internal control. (B) DA D1 activation on activin- and GH-induced follistatin mRNA expression in enriched somatotrophs. Enriched somatotrophs (86-92\% pure) were prepared from mixed populations of carp pituitary cells by Percoll gradient centrifugation and the leftover cells (with only 3-4\% somatotrophs, referred to as the "somatotroph-deficient" cells) were also harvested to serve as a parallel control. The two cell fractions were treated with activin A (10 ng/ml), activin $\mathrm{B}(10 \mathrm{ng} / \mathrm{ml})$, and $\mathrm{GH}(30 \mathrm{ng} / \mathrm{ml})$ for $24 \mathrm{~h}$ in the presence or absence of the D1 agonist SKF77434 (1 $\mu \mathrm{M})$. After that, total RNA was isolated and used for real-time PCR for follistatin mRNA measurement. Data presented are pooled from four experiments $(N=4)$ and the groups denoted by different letters represent a significant different at $P<0.05$.

lactotroph proliferation via local production of TGF $\beta$, a family member of activin (69). To our knowledge, DA D1 regulation of activin/follistatin system has not been documented in mammalian models.

In our recent study, GH and $\mathrm{LH}$ released locally were shown to have differential actions on follistatin expression in carp pituitary cells, with stimulation by GH but inhibition by $\mathrm{LH}$, and the stimulatory effect of GH was mediated by its paracrine induction on activin production (42), which constitutes a local regulation of actvin/follistatin system by pituitary hormones in grass carp. In our study with the same animal model, follistatin mRNA level was up-regulated by GH at pituitary cell 
level and the opposite effect was noted with hCG treatment. Furthermore, GH-induced follistatin gene expression was negated by $\mathrm{D} 1$ activation but the corresponding inhibition by hCG was not additive to that caused by D1 agonist. At present, the role of DA D1 action in LH regulation of actvin/follistatin system is still unclear. However, judging from DA D1 induction of GH release in our previous report (38) and our current findings of D1 inhibition of follistatin expression induced by $\mathrm{GH}$ and follistatin blockade of activin-inhibited $\mathrm{GH}$ gene expression, it would be logical to conclude that dopaminergic input in carp pituitary via D1 receptor activation can modulate the expression as well as pituitary actions of GH via activin/ follistatin system. In our study with LCM isolation of pituitary cells identified by immunostaining, follistatin expression could be located in carp somatotrophs. In enriched faction of carp somatotrophs, the magnitude of follistatin mRNA expression induced by activin A, activin B, and GH (>20-fold vs control) was found to be much higher than the corresponding responses in "somatotroph-deficient" cell fraction or mixed populations of carp pituitary cells ( 2-3-fold vs control) and these stimulatory effects could be notably suppressed by D1 agonist. These findings, taken together, suggest that the somatotrophs may serve as a major site of action for follistatin regulation by activin and $\mathrm{GH}$ as well as their functional interaction with dopaminergic input via $\mathrm{D} 1$ activation in the carp pituitary.

In summary, grass carp follistatin has been cloned and found to be a single-copy gene in the carp genome. Its transcript expression has been demonstrated in the carp pituitary as well as in other tissues. At pituitary level, protein expression of follistatin, together with activin $\beta \mathrm{A}$ and $\beta \mathrm{B}$, has been confirmed and follistatin transcript signals could be detected in carp somatotrophs, lactotrophs, and gonadotrophs. Functional expression also revealed that follistatin of carp origin could nullify activin action in transactivating target promoter with activin-responsive elements. Based on our studies with carp pituitary cells and enriched somatotrophs, follistatin has been confirmed to be a functional component for autocrine/paracrine regulation at the pituitary level and a working model for its role in activin/follistatin system related to $\mathrm{GH}$ regulation in carp pituitary has been proposed (Figure 8). In this model, activin $\mathrm{A}$ and $\mathrm{B}$ released locally induce follistatin mRNA expression in different pituitary cell types and subsequent production of follistatin, especially in carp somatotrophs, can exert a negative feedback to inhibit activin-induced follistatin expression. In carp pituitary cells, GH release is known to stimulate activin expression, which in turn can trigger an inhibitory feedback to suppress GH release and GH gene expression (42). However, the inhibitory effect of activin A and B on GH gene expression can also be negated by local production of follistatin, presumably caused by activin-induced follistatin expression. In carp species, dopaminergic input from the hypothalamus via DA D1 receptor activation is known to induce GH release at pituitary level (38). Interestingly, DA D1 activation in carp pituitary cells, especially in somatotrophs, can suppress both basal as well as activin- and $\mathrm{GH}$-induced follistatin expression. These inhibitory actions mediated by DA D1 receptor presumably can help to relief the activin feedback on $\mathrm{GH}$ production from follistatin inhibition,

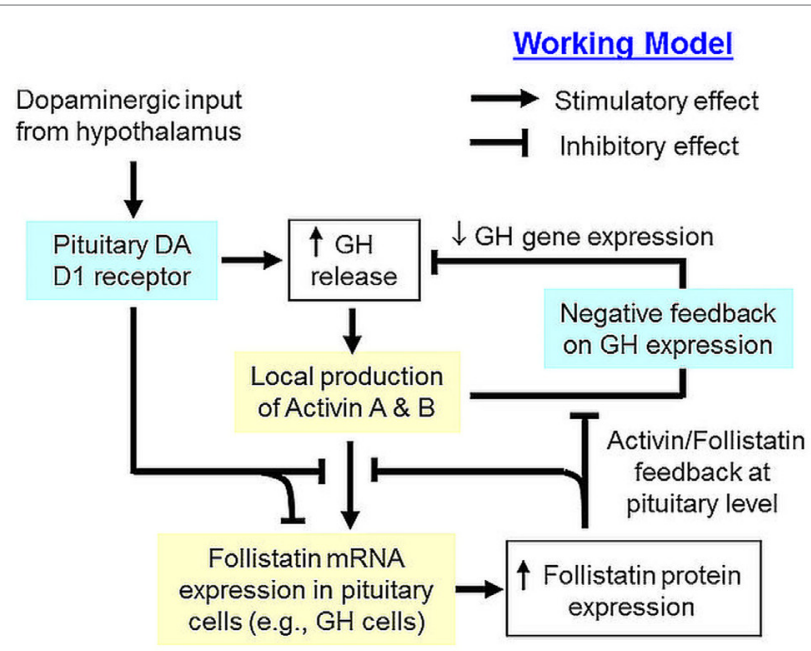

FIGURE 8 | Working model of dopaminergic D1 interaction with activin/ follistatin system for growth hormone $(\mathrm{GH})$ regulation in the carp pituitary. In the carp pituitary, local release of GH can induce activin A and B production, which can exert a negative feedback to inhibit GH secretion and GH gene expression. Meanwhile, pituitary expression of follistatin, especially in carp somatotrophs, is also up-regulated by activin A and B, which can trigger a feedback inhibition to suppress the stimulatory effects of activin on follistatin and $\mathrm{GH}$ gene expression. Dopaminergic input from the hypothalamus, which is well-documented to stimulate $\mathrm{GH}$ release via activation of pituitary dopamine (DA) D1 receptor, can inhibit both basal as well as activin- and $\mathrm{GH}$-induced follistatin expression at pituitary level. This DA D1 action presumably can relief activin feedback on $\mathrm{GH}$ regulation from the inhibitory effect of follistatin, which is a major component for signal termination of activin/follistatin system at tissue level.

which may fine tune the process of GH regulation by activin/follistatin system in the carp pituitary. Our study for the first time provide evidence that dopaminergic interaction with activin/ follistatin system via D1 receptor expressed at pituitary level may form a new facet for GH regulation by autocrine/paracrine mechanisms in carp model.

\section{ETHICS STATEMENT}

The study was conducted according to the recommended guidelines for the care and use of laboratory animals for research and teaching at the University of Hong Kong (Hong Kong).

\section{AUTHOR CONTRIBUTIONS}

AW and RF were responsible for project planning, data analysis, and manuscript writing. RF and $\mathrm{BJ}$ were involved in molecular cloning and functional studies. $\mathrm{MH}$ and $\mathrm{KY}$ were involved in LC/ MS/MS and somatotroph preparation.

\section{ACKNOWLEDGMENTS}

Support from the School of Biological Sciences, University of Hong Kong, in the form of postgraduate studentship (to RF and BJ) 
is also acknowledged. We also thank Prof. C. Peng (York University) for sending us the plasmids of pAR3-Lux and FAST-2 for functional testing of carp follistatin.

\section{FUNDING}

The project was supported by HMRF grant (13142591) from Food and Health Bureau (Hong Kong) and GRF grants (780312,

\section{REFERENCES}

1. Esch FS, Shimasaki S, Mercado M, Cooksey K, Ling N, Ying S, et al. Structural characterization of follistatin: a novel follicle-stimulating hormone releaseinhibiting polypeptide from the gonad. Mol Endocrinol (1987) 1:849-55. doi:10.1210/mend-1-11-849

2. Choi SC, Han JK. Negative regulation of activin signal transduction. Vitam Horm (2011) 85:79-104. doi:10.1016/B978-0-12-385961-7.00005-6

3. Macqueen DJ, Johnston IA. Evolution of follistatin in teleosts revealed through phylogenetic, genomic and expression analyses. Dev Genes Evol (2008) 218:1-14. doi:10.1007/s00427-007-0194-8

4. Bilezikjian LM, Vale WW. The local control of the pituitary by activin signaling and modulation. Open Neuroendocrinol J (2011) 4:90-101. doi:10.2174/1876 528901104010090

5. Wijayarathna R, de Kretser DM. Activins in reproductive biology and beyond. Hum Reprod Update (2016) 22(3):dmv058. doi:10.1093/humupd/dmv058

6. Walton KL, Makanji Y, Harrison CA. New insights into the mechanisms of activin action and inhibition. Mol Cell Endocrinol (2012) 359:2-12. doi:10.1016/j.mce.2011.06.030

7. Han XH, Jin YR, Tan L, Kosciuk T, Lee JS, Yoon JK. Regulation of the follistatin gene by RSPO-LGR4 signaling via activation of the $\mathrm{WNT} / \beta$-catenin pathway in skeletal myogenesis. Mol Cell Biol (2014) 34:752-64. doi:10.1128/ MCB.01285-13

8. Jones AE, Price FD, Le Grand F, Soleimani VD, Dick SA, Megeney LA, et al. Wnt/ $\beta$-catenin controls follistatin signalling to regulate satellite cell myogenic potential. Skelet Muscle (2015) 5:14. doi:10.1186/s13395-015-0038-6

9. Knight PG, Satchell L, Glister C. Intra-ovarian roles of activins and inhibins. Mol Cell Endocrinol (2012) 359:53-65. doi:10.1016/j.mce.2011.04.024

10. de Kretser DM, Buzzard JJ, Okuma Y, O'Connor AE, Hayashi T, Lin SY, et al. The role of activin, follistatin and inhibin in testicular physiology. Mol Cell Endocrinol (2004) 225:57-64. doi:10.1016/j.mce.2004.07.008

11. Florio P, Gabbanini M, Borges LE, Bonaccorsi L, Pinzauti S, Reis FM, et al. Activins and related proteins in the establishment of pregnancy. Reprod Sci (2010) 17:320-30. doi:10.1177/1933719109353205

12. Refaat B. Role of activins in embryo implantation and diagnosis of ectopic pregnancy: a review. Reprod Biol Endocrinol (2014) 12:116. doi:10.1186/ 1477-7827-12-116

13. Bilezikjian LM, Justice NJ, Blackler AN, Wiater E, Vale WW. Cell-type specific modulation of pituitary cells by activin, inhibin and follistatin. Mol Cell Endocrinol (2012) 359:43-52. doi:10.1016/j.mce.2012.01.025

14. Hansen JS, Plomgaard P. Circulating follistatin in relation to energy metabolism. Mol Cell Endocrinol (2016) 433:87-93. doi:10.1016/j.mce.2016.06.002

15. Braga M, Reddy ST, Vergnes L, Pervin S, Grijalva V, Stout D, et al. Follistatin promotes adipocyte differentiation, browning, and energy metabolism. J Lipid Res (2014) 55:375-84. doi:10.1194/jlr.M039719

16. Hedger MP, Winnall WR, Phillips DJ, de Kretser DM. The regulation and functions of activin and follistatin in inflammation and immunity. Vitam Horm (2011) 85:255-97. doi:10.1016/B978-0-12-385961-7.00013-5

17. de Kretser DM, O'Hehir RE, Hardy CL, Hedger MP. The roles of activin A and its binding protein, follistatin, in inflammation and tissue repair. Mol Cell Endocrinol (2012) 359:101-6. doi:10.1016/j.mce.2011.10.009

18. Hedger MP, de Kretser DM. The activins and their binding protein, follistatindiagnostic and therapeutic targets in inflammatory disease and fibrosis. Cytokine GrowthFactorRev (2013)24:285-95.doi:10.1016/j.cytogfr.2013.03.003

19. Rodriguez-Martinez G, Velasco I. Activin and TGFßeffects on brain development and neural stem cells. CNS Neurol Disord Drug Targets (2012) 11(7):844-55. doi:10.2174/1871527311201070844
781113, 17128215, and 17117716) and NSFC/RGC Joint Grant (N_HKU 732/12) from Research Grant Council (Hong Kong).

\section{SUPPLEMENTARY MATERIAL}

The Supplementary Material for this article can be found online at http://journal.frontiersin.org/article/10.3389/fendo.2017.00211/ full\#supplementary-material.

20. Shi L, Resaul J, Owen S, Ye L, Jiang WG. Clinical and therapeutic implications of follistatin in solid tumours. Cancer Genomics Proteomics (2016) 13(6):425-35. doi:10.21873/cgp.20005

21. Chen PR, Lee K. Invited review: inhibitors of myostatin as methods of enhancing muscle growth and development. J Anim Sci (2016) 94:3125-34. doi:10.2527/jas.2016-0532

22. Roberts VJ, Peto CA, Vale W, Sawchenko PE. Inhibin/activin subunits are costored with FSH and LH in secretory granules of the rat anterior pituitary gland. Neuroendocrinology (1992) 56:214-24. doi:10.1159/000126231

23. Gregory SJ, Kaiser UB. Regulation of gonadotropins by inhibin and activin. Semin Reprod Med (2004) 22:253-67. doi:10.1055/s-2004-831901

24. Bilezikjian LM, Leal AM, Blount AL, Corrigan AZ, Turnbull AV, Vale WW. Rat anterior pituitary folliculostellate cells are targets of interleukin-1b $\beta$ and a major source of intra-pituitary follistatin. Endocrinology (2003) 144:732-40. doi:10.1210/en.2002-220703

25. Bilezikjian LM, Corrigan AZ, Vaughan JM, Vale WM. Activin-A regulates follistatin secretion from cultured rat anterior pituitary cells. Endocrinology (1993) 133(6):2554-60. doi:10.1210/endo.133.6.8243277

26. Bilezikjian LM, Blount AL, Leal AM, Donaldson CJ, Fischer WH, Vale WW. Autocrine/paracrine regulation of pituitary function by activin, inhibin and follistatin. Mol Cell Endocrinol (2004) 225:29-36. doi:10.1016/j. mce.2004.02.010

27. Coss D, Thackray VG, Deng CX, Mellon PL. Activin regulates luteinizing hormone $\beta$-subunit gene expression through Smad-binding and homeobox elements. Mol Endocrinol (2005) 19:2610-23. doi:10.1210/me.20050047

28. Gong FY, Deng JY, Zhu HJ, Pan H. Activin inhibits the promoter activity of human growth hormone gene in rat pituitary GH3 cells. Sheng Li Xue Bao (2010) 62:49-54

29. Tamura N, Irahara M, Kuwahara A, Ushigoe K, Sugino H, Aono T. Effect of activin on production and secretion of prolactin and growth hormone in cultured rat GH3 cells. Eur J Endocrinol (2000) 142:506-11. doi:10.1530/ eje.0.1420506

30. Ge W. Roles of the activin regulatory system in fish reproduction. Can J Physiol Pharmacol (2000) 78:1077-85. doi:10.1139/y00-102

31. Yam KM, Yoshiura Y, Kobayashi M, Ge W. Recombinant goldfish activin B stimulates gonadotropin-Ibeta but inhibits gonadotropin-II $\beta$ expression in the goldfish, Carassius auratus. Gen Comp Endocrinol (1999) 116:81-9. doi:10.1006/gcen.1999.7339

32. Lin SW, Ge W. Differential regulation of gonadotropins (FSH and LH) and growth hormone $(\mathrm{GH})$ by neuroendocrine, endocrine, and paracrine factors in the zebrafish-an in vitro approach. Gen Comp Endocrinol (2009) 160:183-93. doi:10.1016/j.ygcen.2008.11.020

33. Aroua S, Maugars G, Jeng SR, Chang CF, Weltzien FA, Rousseau K, et al. Pituitary gonadotropins FSH and $\mathrm{LH}$ are oppositely regulated by the activin/ follistatin system in a basal teleost, the eel. Gen Comp Endocrinol (2012) 175(1):82-91. doi:10.1016/j.ygcen.2011.10.002

34. Cheng GF, Yuen CW, Ge W. Evidence for the existence of a local activin follistatin negative feedback loop in the goldfish pituitary and its regulation by activin and gonadal steroids. J Endocrinol (2007) 195(3):373-84. doi:10.1677/ JOE-07-0265

35. Yuen CW, Ge W. Follistatin suppresses FSH $\beta$ but increases LH $\beta$ expression in the goldfish-evidence for an activin-mediated autocrine/paracrine system in fish pituitary. Gen Comp Endocrinol (2004) 135(1):108-15. doi:10.1016/j. ygcen.2003.08.012

36. Wong AO, Zhou H, Jiang Y, Ko WK. Feedback regulation of growth hormone synthesis and secretion in fish and the emerging concept of intrapituitary 
feedback loop. Comp Biochem Physiol A Mol Integr Physiol (2006) 144:284-305. doi:10.1016/j.cbpa.2005.11.021

37. Lin C, Jiang X, Hu G, Ko WK, Wong AO. Grass carp prolactin: molecular cloning, tissue expression, intrapituitary autoregulation by prolactin and paracrine regulation by growth hormone and luteinizing hormone. Mol Cell Endocrinol (2015) 399:267-83. doi:10.1016/j.mce.2014.10.010

38. Wong AO, Ng S, Lee EK, Leung RC, Ho WK. Somatostatin inhibits (D-Arg', Pro $^{9}-\mathrm{NEt}$ ) salmon gonadotropin-releasing hormone- and dopamine D1-stimulated growth hormone release from perifused pituitary cells of chinese grass carp, Ctenopharyngodon idellus. Gen Comp Endocrinol (1998) 110:29-45. doi:10.1006/gcen.1997.7045

39. Zhou H, Wang X, Ko WK, Wong AO. Evidence for a novel intrapituitary autocrine/paracrine feedback loop regulating growth hormone synthesis and secretion in grass carp pituitary cells by functional interactions between gonadotrophs and somatotrophs. Endocrinology (2004) 145:5548-59. doi:10.1210/en.2004-0362

40. Zhou H, Jiang Y, Ko WK, Li W, Wong AO. Paracrine regulation of growth hormone gene expression by gonadotrophin release in grass carp pituitary cells: functional implications, molecular mechanisms and signal transduction. J Mol Endocrinol (2005) 34:415-32. doi:10.1677/jme.1.01629

41. Zhou H, Ko WK, Ho WK, Stojilkovic SS, Wong AO. Novel aspects of growth hormone (GH) autoregulation: GH-induced GH gene expression in grass carp pituitary cells through autocrine/paracrine mechanisms. Endocrinology (2004) 145:4615-28. doi:10.1210/en.2004-0163

42. Fung RSK, Bai J, Yuen KWY, Wong AOL. Activin/follistatin system in grass carp pituitary cells:-regulation by local release of growth hormone and luteinizing hormone and its functional role in growth hormone synthesis and secretion. PLoS One (2017) 12:e179789. doi:10.1371/journal.pone.0179789

43. Agustsson T, Ebbesson LO, Bjornsson BT. Dopaminergic innervation of the rainbow trout pituitary and stimulatory effect of dopamine on growth hormone secretion in vitro. Comp Biochem Physiol A Mol Integr Physiol (2000) 127:355-64. doi:10.1016/S1095-6433(00)00265-8

44. Kah O, Dulka JG, Dubourg P, Thibault J, Peter RE. Neuroanatomical substrate for the inhibition of gonadotrophin secretion in goldfish: existence of a dopaminergic preoptico-hypophyseal pathway. Neuroendocrinology (1987) 45:451-8. doi:10.1159/000124774

45. Wong AO, Chang JP, Peter RE. In vitro and in vivo evidence that dopamine exerts growth hormone-releasing activity in goldfish. Am J Physiol (1993) 264:E925-32.

46. Melamed P, Gur G, Elizur A, Rosenfeld H, Sivan B, Rentier-Delrue F, et al. Differential effects of gonadotropin-releasing hormone, dopamine and somatostatin and their second messengers on the mRNA levels of gonadotropin II $\beta$ subunit and growth hormone in the teleost fish, tilapia. Neuroendocrinology (1996) 64:320-8. doi:10.1159/000127135

47. Chang JP, Yu KL, Wong AO, Peter RE. Differential actions of dopamine receptor subtypes on gonadotropin and growth hormone release in vitro in goldfish. Neuroendocrinology (1990) 51:664-74. doi:10.1159/000125408

48. Huo L, Fu G, Wang X, Ko WK, Wong AO. Modulation of calmodulin gene expression as a novel mechanism for growth hormone feedback control by insulin-like growth factor in grass carp pituitary cells. Endocrinology (2005) 146:3821-35. doi:10.1210/en.2004-1508

49. Hu G, He M, Ko WKW, Wong AOL. TAC1 gene products regulate pituitary hormone secretion and gene expression in prepubertal grass carp pituitary cells. Endocrinology (2017) 158:1776-97. doi:10.1210/en.2016-1740

50. Hu G, He M, Ko WK, Lin C, Wong AO. Novel pituitary actions of TAC3 gene products in fish model: receptor specificity and signal transduction for prolactin and somatolactin $\alpha$ regulation by neurokinin B (NKB) and NKBrelated peptide in carp pituitary cells. Endocrinology (2014) 155:3582-96. doi:10.1210/en.2014-1105

51. Fernandez-Vazquez G, Kaiser UB, Albarracin CT, Chin WW. Transcriptional activation of the gonadotropin-releasing hormone receptor gene by activin $\mathrm{A}$. Mol Endocrinol (1996) 10:356-66. doi:10.1210/mend.10.4.8721981

52. Yagi K, Goto D, Hamamoto T, Takenoshita S, Kato M, Miyazono K. Alternatively spliced variant of Smad2 lacking exon 3. Comparison with wild-type Smad2 and Smad3. J Biol Chem (1999) 274:703-9. doi:10.1074/jbc.274.2.703

53. Sun C, He M, Ko WK, Wong AO. Gene expression of luteinizing hormone receptor in carp somatotrophs differentially regulated by local action of gonadotropin and dopamine D1 receptor activation. Mol Cell Endocrinol (2013) 374:22-34. doi:10.1016/j.mce.2013.04.003

54. Shimasaki S, Koga M, Esch F, Mercado M, Cooksey K, Koba A, et al. Porcine follistatin gene structure supports two forms of mature follistatin produced by alternative splicing. Biochem Biophys Res Commun (1988) 152:717-23. doi:10.1016/S0006-291X(88)80097-4

55. Grattan DR. 60 years of neuroendocrinology: the hypothalamo-prolactin axis. J Endocrinol (2015) 226:T101-22. doi:10.1530/JOE-15-0213

56. Harrington AE, Morris-Triggs SA, Ruotolo BT, Robinson CV, Ohnuma S, Hyvonen M. Structural basis for the inhibition of activin signalling by follistatin. EMBO J (2006) 25:1035-45. doi:10.1038/sj.emboj.7601000

57. Nakamura T, Sugino K, Titani K, Sugino H. Follistatin, an activin-binding protein, associates with heparan sulfate chains of proteoglycans on follicular granulosa cells. J Biol Chem (1991) 266:19432-7.

58. Inouye S, Guo Y, DePaolo L, Shimonaka M, Ling N, Shimasaki S. Recombinant expression of human follistatin with 315 and 288 amino acids: chemical and biological comparison with native porcine follistatin. Endocrinology (1991) 129:815-22. doi:10.1210/endo-129-2-815

59. Cataldo NA, Rabinovici J, Fujimoto VY, Jaffe RB. Follistatin antagonizes the effects of activin-A on steroidogenesis in human luteinizing granulosa cells. J Clin Endocrinol Metab (1994) 79:272-7. doi:10.1210/jcem.79.1.7517947

60. Michel U, Rao A, Findlay JK. Rat follistatin: ontogeny of steady-state mRNA levels in different tissues predicts organ-specific functions. Biochem Biophys Res Commun (1991) 180:223-30. doi:10.1016/S0006-291X(05)81280-X

61. Tuuri T, Eramaa M, Hilden K, Ritvos O. The tissue distribution of activin $\beta \mathrm{A}-$ and $\beta \mathrm{B}$-subunit and follistatin messenger ribonucleic acids suggests multiple sites of action for the activin-follistatin system during human development. J Clin Endocrinol Metab (1994) 78:1521-4. doi:10.1210/jcem.78.6. 8200957

62. Wu T, Patel H, Mukai S, Melino C, Garg R, Ni X, et al. Activin, inhibin, and follistatin in zebrafish ovary: expression and role in oocyte maturation. Biol Reprod (2000) 62:1585-92. doi:10.1095/biolreprod62.6.1585

63. Dignass AU, Jung S, Harder-d'Heureuse J, Wiedenmann B. Functional relevance of activin A in the intestinal epithelium. Scand J Gastroenterol (2002) 37:936-43. doi:10.1080/003655202760230900

64. Necela BM, Su W, Thompson EA. Peroxisome proliferator-activated receptor gamma down-regulates follistatin in intestinal epithelial cells through SP1. J Biol Chem (2008) 283:29784-94. doi:10.1074/jbc.M804481200

65. Sekiguchi M, Hayashi F, Tsuchida K, Inokuchi K. Neuron type-selective effects of activin on development of the hippocampus. Neurosci Lett (2009) 452:232-7. doi:10.1016/j.neulet.2009.01.074

66. Florio P, Gazzolo D, Luisi S, Petraglia F. Activin A in brain injury. Adv Clin Chem (2007) 43:117-30. doi:10.1016/S0065-2423(06)43004-3

67. Weisinger K, Wilkinson DG, Sela-Donenfeld D. Inhibition of BMPs by follistatin is required for FGF3 expression and segmental patterning of the hindbrain. Dev Biol (2008) 324:213-25. doi:10.1016/j.ydbio.2008.09.005

68. Fujii Y, Okada Y, Moore JP Jr, Dalkin AC, Winters SJ. Evidence that PACAP and GnRH down-regulate follicle-stimulating hormone $\beta$ mRNA levels by stimulating follistatin gene expression: effects on folliculostellate cells, gonadotrophs and L $\beta$ T2 gonadotroph cells. Mol Cell Endocrinol (2002) 192:55-64. doi:10.1016/S0303-7207(02)00109-0

69. Sarkar DK, Chaturvedi K, Oomizu S, Boyadjieva NI, Chen CP. Dopamine, dopamine D2 receptor short isoform, transforming growth factor (TGF)- $\beta 1$, and TGF- $\beta$ type II receptor interact to inhibit the growth of pituitary lactotropes. Endocrinology (2005) 146:4179-88. doi:10.1210/en.2005-0430

Conflict of Interest Statement: The research was conducted in the absence of any commercial or financial relationships that could be construed as a potential conflict of interest.

Copyright (c) 2017 Fung, Jin, He, Yuen and Wong. This is an open-access article distributed under the terms of the Creative Commons Attribution License (CC BY). The use, distribution or reproduction in other forums is permitted, provided the original author(s) or licensor are credited and that the original publication in this journal is cited, in accordance with accepted academic practice. No use, distribution or reproduction is permitted which does not comply with these terms. 